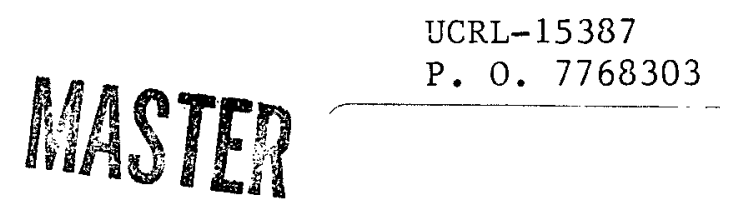

\title{
UCRL--15387
}

\section{DE82 006925}

\author{
LOCATION OF ODOR SOURCES AND THE \\ AFFECTED POPULATIOIN IN \\ IMPERIAL COUNTY, CALIFORNIA
}

Jeffrey L. Hahn, P.E.

California Department of Health Services

Berkeley, CA 04704 


\section{DISCLAIMER}

This report was prepared as an account of work sponsored by an agency of the United States Government. Neither the United States Government nor any agency Thereof, nor any of their employees, makes any warranty, express or implied, or assumes any legal liability or responsibility for the accuracy, completeness, or usefulness of any information, apparatus, product, or process disclosed, or represents that its use would not infringe privately owned rights. Reference herein to any specific commercial product, process, or service by trade name, trademark, manufacturer, or otherwise does not necessarily constitute or imply its endorsement, recommendation, or favoring by the United States Government or any agency thereof. The views and opinions of authors expressed herein do not necessarily state or reflect those of the United States Government or any agency thereof. 


\section{DISCLAIMER}

Portions of this document may be illegible in electronic image products. Images are produced from the best available original document. 


\section{DISCLAIMER}

This document was prepared as an account of work sponsored by an agency of the United States Government. Neither the United States Government nor the University of California nor any of their employees, makes any warranty, express or implied, or assumes any legal liability or responsibility for the accuracy, completeness, or usefulness of any information, apparatus, product, or process disclosed, or represents that its use would not infringe privately owned rights. Reference herein to any specific commercial products, process, or service by trade name, trademark, manufacturer, or otherwise, does not necessarily constitute or imply its endorsement, recommendation, or favoring by the United States Government or the University of California. The views and opinions of authors expressed herein do not necessarily state or reflect those of the United States Government thereof, and shall not be used for advertising or product endorsement purposes.

Work performed under the auspices of the U.S. Department of Energy by Lawrence Livermore National Laboratory under Contract W-7405-Eng-48. 
Location of Odor Sources

and the Affected Population in

Imperial County, California

Jeffrey L. Hahn, P.E.

California Department of Health Services

Berkeley, CA 04704

August 1981

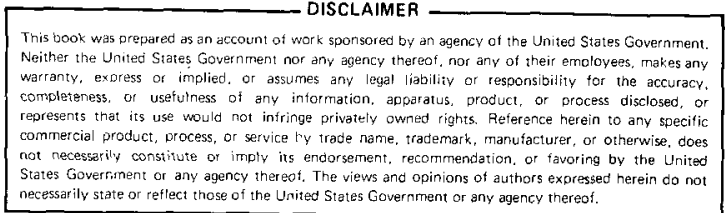

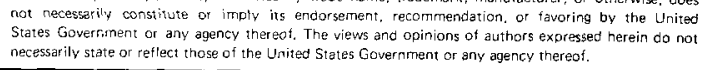




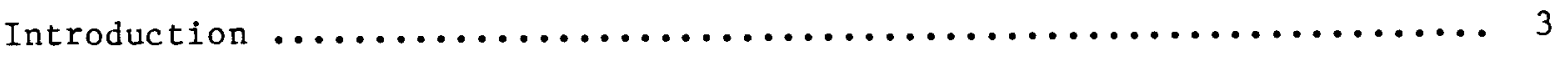

General Geographical and Geothermal Resource Description ........... 3

General Meteorological Description $\ldots \ldots \ldots \ldots \ldots \ldots \ldots \ldots \ldots \ldots \ldots \ldots$

General Discussion of Odor Sources $\ldots \ldots \ldots \ldots \ldots \ldots \ldots \ldots \ldots \ldots \ldots \ldots$

Dispersed Odor Sources: Fertilizers, Pesticides, and

Agricultural Burning.$\ldots \ldots \ldots \ldots \ldots \ldots \ldots \ldots \ldots \ldots \ldots \ldots \ldots \ldots \ldots$

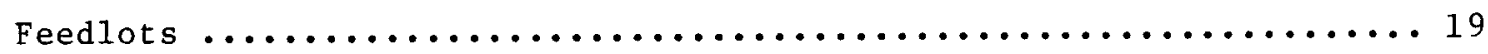

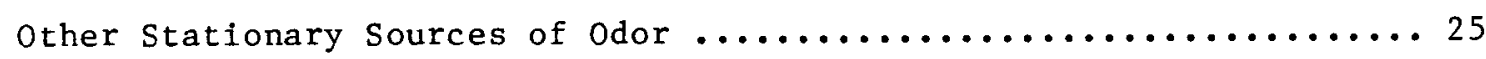

Odor Source Location and Mapping of Areas of Odor Perception and

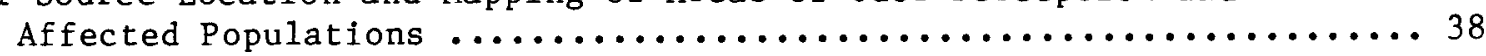

References $\ldots \ldots \ldots \ldots \ldots \ldots \ldots \ldots \ldots \ldots \ldots \ldots \ldots \ldots \ldots \ldots \ldots \ldots \ldots \ldots$

Appendix: Letters of Comment $\ldots \ldots \ldots \ldots \ldots \ldots \ldots \ldots \ldots \ldots \ldots \ldots \ldots \ldots \ldots$ 


\section{INTRODUCTION}

To identify the location of odor sources and possible components causing the odors in Imperial County, a comprehensive investigation of potential odor sources, including air pollution and meteorological data, was completed. This report fulfills the obligation of Task $G$ in the contract on "Estimating Health Impact of Geothermal Development in Imperial County, California" performed for the Lawrence Livermore Laboratory by the Epidemiological Studies Laboratory Section, Department of Health Services. This report is divided into four sections. The first two sections contain general background information on Imperial County. The third section is a general discussion of odor sources in Imperial County, and the fourth maps the specific odor sources, the expected areas of perception, and the affected populations. This mapping is done for the Imperial Valley and each of the four Imperial County KGRA's (Known Geothermal Resource Areas) where odor from the development of the geothermal energy may affect population.

\section{GENERAL GEOGRAPHICAL AND GEOTHERMAL RESOURCE DESCRIPTION*}

Imperial County is the southeasternmost county in California and is bounded on the south by the Republic of Mexico, on the east by Arizona, on the west by San Diego County, and on the north by Riverside County.

*From D. Layton, D. Ermak. A Description of Imperial Valley, California, for the Assessment of Impacts of Geothermal Energy Development. Lawrence Livermore Laboratory, Livermore, Calif., UCRL-52121 (1976) ${ }^{1}$ and Imperial County Air Pollution Control District, Imperial County Plan to Attain National Ambient Air Standards for Oxidants (October 31, 1978). ${ }^{2}$ 
Imperial County contains a broad desert basin bounded on the east and west by mountains. On the eastern boundary is the Colorado River. Elevations in the county range from 232 feet below sea level to 2700 feet in the Chocolate mountains.

The Imperial Valley occupies part of a rift valley known as the Salton Trough. This trough extends from the Gulf of California to the northern segment of the Coachella Valley. Volcanic activity is associated with parts of the trough.

The U.S. Geological Survey has designated a number of areas in the State of California as Known Geothermal Resource Areas (KGRAs). Six KGRAs are located within the Imperial Valley. They are the Brawley, Dunes, East Mesa, Glamis, Heber, and Salton Sea KGRAs. Figure 1 shows their location, boundaries, and areas. These areas were designated as KGRAs on the basis of temperature gradient measurements made within the valley. An additional area east of Brawley appears to contain a deep-seated heat source; however, this area has not undergone extensive exploration and has not been designated as a KGRA.

A11 the geothermal systems in the Imperial Valley are liquid-dominated. Geothermal resources at a temperature of about $150^{\circ} \mathrm{C}$ may be considered for generation of electricity, while those below $150^{\circ} \mathrm{C}$ are attractive for space and process heating. Of the six Imperial County KGRAs, four have resources above $150^{\circ} \mathrm{C}$ : Brawley, East Mesa, Heber, and Salton Sea. These areas are also sufficiently large to be of potential economic value, (and have populations that could be affected by the development of geothermal energy). 
GENERAL METEOROLOGICAL DESCRIPTION ${ }^{+}$

Imperial County has a desert climate with hot dry summers and mild winters. There is very little variation in climate throughout the County, with the exception of higher humidities in the irrigated areas, and local differences in winds due to topography.

The average temperature in Imperial County during the month of January is about $55^{\circ} \mathrm{F}$ and in July is around $90^{\circ} \mathrm{F}$. As a result of high mountain ranges separating the valley from the California coast, the county's climate is of continental character. Modified marine air comes from the Pacific Ocean via the San Gorgonio Pass and the Coachella Valley and also through the lower end of the Salton Trough from the Gulf of California. Due to high insolation during the day and strong radiative cooling during the night, average diurnal temperature ranges are $20^{\circ} \mathrm{F}$ to $30^{\circ} \mathrm{F}$ throughout the year.

There is very little precipitation in the Imperial County. The rainy season is August through March, and rainfall averages 3 hours per month. Almost all of the County receives four or fewer inches of rain annually. June is the driest month with measurable rainfall occurring only once $(0.04$ inches on June 2,1948 ) since 1914. The average yearly rainfall is 2.73 inches. Yearly averages may be misleading, however, as there is considerable variation in rainfall from year to year. Yearly rainfall has varied from a fraction of an inch to over 8 inches. The valley has little fog and few thunderstorms.

\footnotetext{
From Imperial County Air Pollution Control District; Imperial County Plan to Attain National Ambient Air Standards for Oxidants (October 31, 1978).
} 


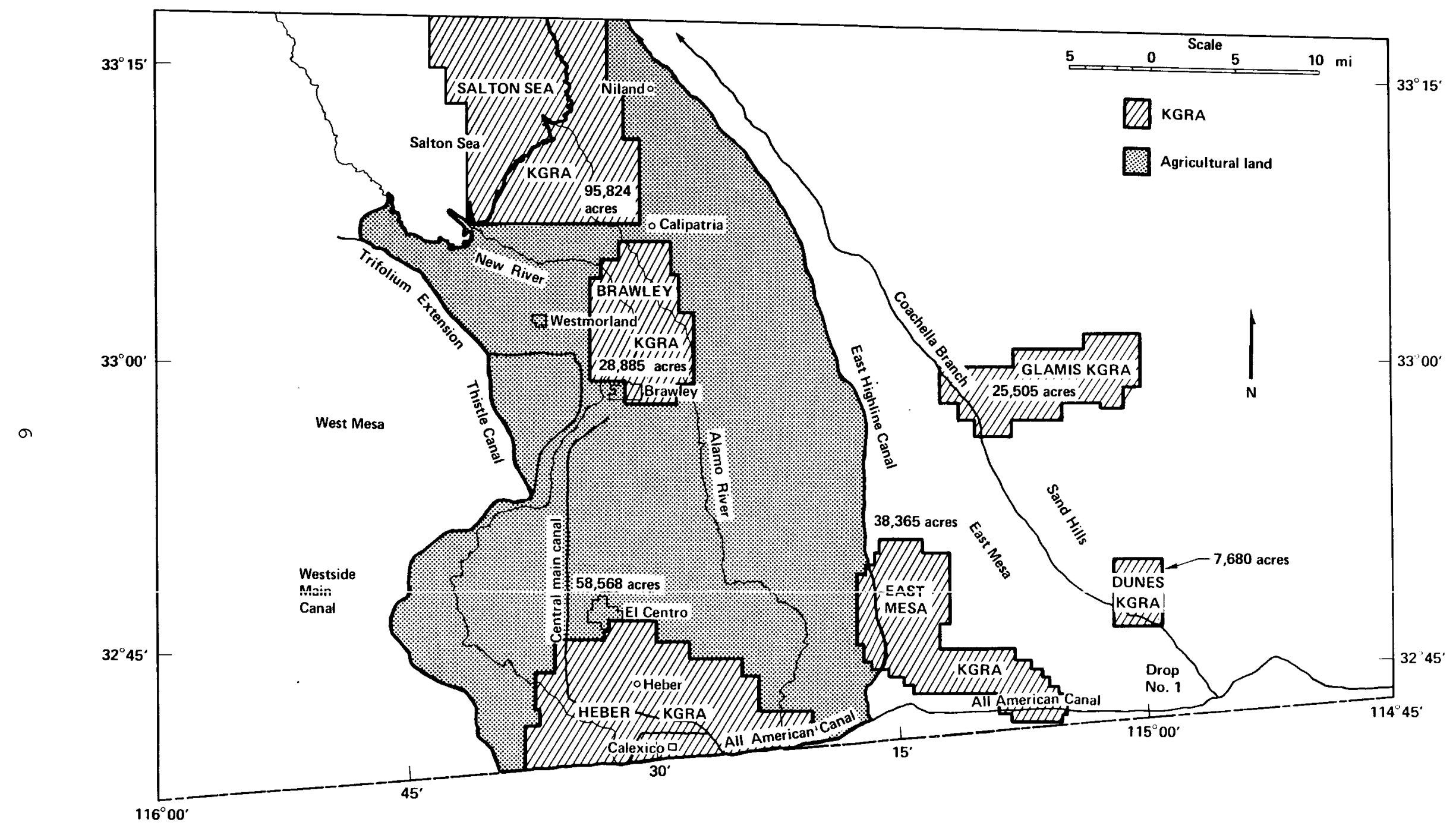

Fig. 1. Locations of the six known geothermal resource areas in Imperial Valley. (From D. Layton, D. Ermak. A Description of Imperial Valley,

California, for the Assessment of Impacts of Geothermal Energy Development. Lawrence Livermore Laboratory, Livermore, Calif., UCRL-52121 (1976). 
Imperial County winds mainly come from three directions: west, northwest and southeast. The westerly winds are prevalent most of the year, while southeasterly winds occur with greater frequency in July and August. Westerly winds come through high mountain gaps from the San Diego area. Southeasterly winds bring in modified air off the Gulf of California. Northwesterly winds also bring in modified marine air from the South Coast Air Basin.

During the winter westerly winds dominate the day from late evening until approximately 0900 PST the next morning. Iuring the middle of the day the very light north and northwesterly winds result in relatively calm conditions. Southeasterly winds are infrequent during this time of the year.

The change to spring brings greater insolation due to increased day length and the higher angle of the sun. This heating causes a thermal low, occasionally drawing in air off the gulf during the afternoon. However, westerly winds dominate the day with occasional northwesterly winds in the late evening. Upper air data indicates winds aloft are commonly from the north and northwest during the morning hours.

During the summer the thermal low becomes very intense, causing a strong flow of air off the gulf. During this time winds are predominantly from the southeast, except for occasional westerly winds during the late evening and early morning hours. During the fall southeasterly winds taper off until they occur only during the early afternoon hours. As the season progresses the frequency of calm conditions increases.

The relative humidity in the Imperial Valley is very low, averaging 30 to 50 percent in the morning and decreasing to 10 to 20 percent in the late afternoon. A relative humidity of 10 percent is common on hot summer 
afternoons. The low humidity results in intense heating of the Valley during the day and very cool temperatures at night. On more than 100 days of the year, during the summer months, temperatures usually exceed $100^{\circ} \mathrm{F}$. Mean annual relative humidity is 38 percent. Clouds and fog occur infrequently in the desert area.

Imperial County experiences surface inversions almost every day of the year. Due to strong surface heating, these inversions are usually broken allowing pollutants to more easily disperse. Subsidence inversions are common from November through June, but appear to be relatively absent July through October.

\section{GENERAL DISCUSSION OF ODOR SOURCES}

To compile the location of odors in Imperial County and then to identify the possible components causing the odors, a general survey was conducted of all the possible sources of odors. This section describes county-wide odor sources both from general dispersed sources and defined stationary sources. Fertilizers and pesticides used in agriculture are the major dispersed sources of odor. The stationary sources include feedlots and the other sources permitted by the Imperial County Air Pollution Control District, including some existing geothermal development. Where available, the distinct components of the odor are given, as well as the distance of odor transport, i.e., the areal extent of perceptible odor, in square miles. With the above information, odor mapping for the sources in each of the Imperial County KGRAs will be possible. Also, some previous work by the Department of Health Services on health and odor in Imperial County is presented as it gives a historical perspective to Imperial County's attitude toward odor and health. 
DISPERSED ODOR SOURCES: FERTILIZERS, PESTICIDES, AND AGRICULTURAL BURNING

Odors from agricultural operations are produced over large areas and are considered as a dispersed source of odor. The use of fertilizers, pesticides, and agricultural burning are the major offensive odor sources. Fertilizers

Many complaints have been made of the odor from ammonia ${ }^{3}$ caused by irrigating with liquid ammonia fertilizers. In 1975, out of the 240,355 total tons of fertilizer containing 67,578 tons of nitrogen (assumed as $\left.\mathrm{NH}_{3}\right), 152,473$ tons of liquid fertilizer were sold. ${ }^{1}$ Also, complaints were made of odor from $\mathrm{H}_{2} \mathrm{~S}$ from irrigating with liquid sulfur solutions. ${ }^{3}$ The two most commonly used are Nitra-Sul (sulfur dissolved in an ammonia-water solution) and liquid lime-sulfur solutions (lime, sulfur, and water reacted together to form a solution of calcium polysulfide, free sulfur, and calcium thiosulfate).

On application $\mathrm{H}_{2} \mathrm{~S}$ is evolved from these solutions. Nitra-Sul is mainly used in irrigation water for lettuce and grains. In 1975, 4,743 tons of liquid sulfur solutions containing 1,163 tons of sulfur were sold. ${ }^{1}$ In Fig. 2, we can see that the $\mathrm{H}_{2} \mathrm{~S}$ concentrations at East Mesa are higher at certain periods during the year. ${ }^{4}$ Two such periods are July and November. From production calendars of Imperial County crops, ${ }^{1}$ we find that sorghum grains are fertilized in July and lettuce in November. From the agricultural resources maps, ${ }^{5}$ we find that both of those crops are grown close to East Mesa. If Nitra-Sul or a liquid lime-sulfur solution were used, we can thus explain the higher $\mathrm{H}_{2} \mathrm{~S}$ readings.

Complaints have been made of odor from spreading manure on fields to fertilize vegetable crops. ${ }^{3}$ Fields that are over 200 acres with 
fertilizer loadings in the range of 20 to 40 tons or more per acre contribute substantially to odor.

The odors from the application of fertilizers can be transported large distances, and these odor-producing materials also are used close to population centers in the Imperial Valley. Both factors must be considered in odor determinations and mapping. Since fertilizers are used on all crop types, the mapping will be useful to show general areas of fertilizer odor in contrast to nonagricultural and idle land.

$\underline{\text { Pesticides }}$

The use of certain pesticides in Imperial County has caused odor complaints, ${ }^{3}$ while other pesticides used in large amounts have the potential for annoyance from odor. Bolstar, DEF, and Folex are the most potent, producing a strong, lasting odor that can be transported. The use of Bolstar and other pesticides created many odor and health complaints in their application near Phoenix, Arizona in $1978 .^{6}$ Since Bolstar, DEF, and Folex are only used on cotton, probable areas of odor annoyance can be determined from field-crop land-use data (see Figs. 3 through 5). Table 1 lists the most odorous pesticides in pounds sold in 1975, along with the most used pesticides with an odor potential, and major crops for which these pesticides are used. The use of this table, along with the agricultural resource maps will allow mapping of other potential sources of pesticide odor annoyance in each of the four major Imperial County KGRAs -- those with populations possibly affected by odor. The mapping can only estimate field usage, since crops are rotated; all odor-annoyance mapping will be approximate, except when, for example, field crops with certain pesticide usage predominate, such as cotton or sugar beets. 


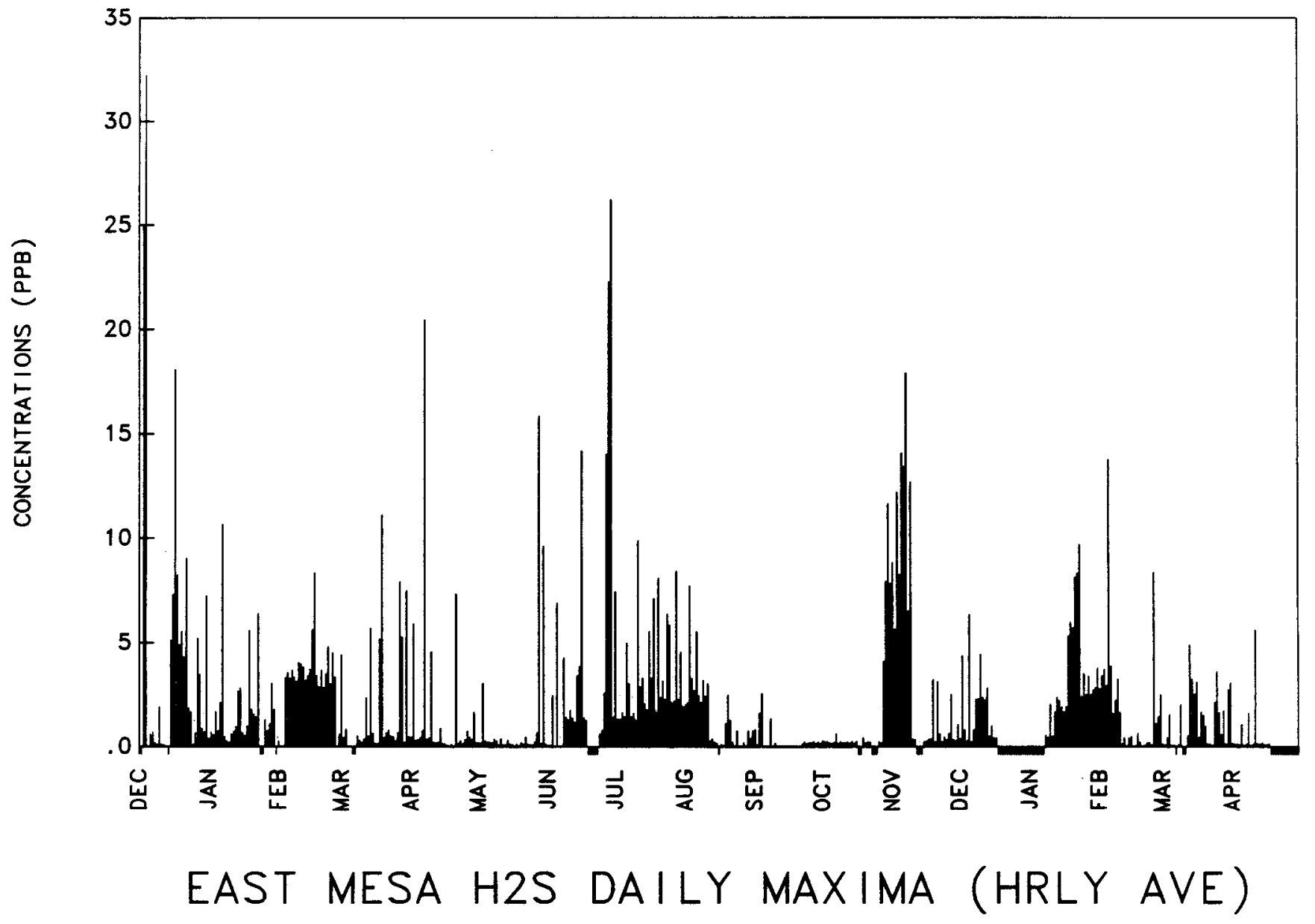

Fig. 2. Concentrations of $\mathrm{H}_{2} \mathrm{~S}$ at East Mesa.4 Note that two of the periods of high $\mathrm{H}_{2} \mathrm{~S}$ concentration are in July and in November when sorghum grains and lettuce are fertilized, respectively. 


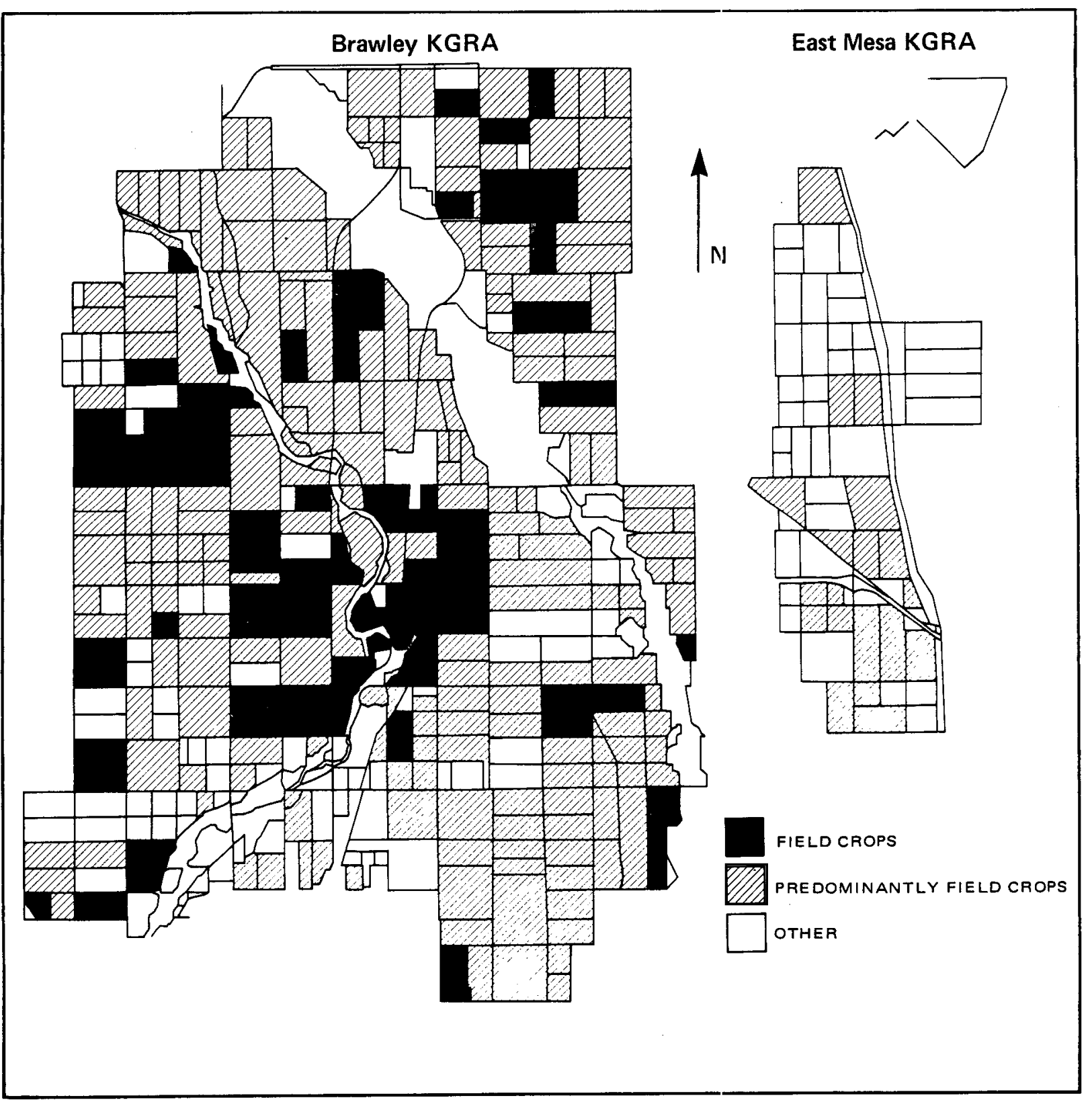

Fig. 3. Agricultural resource maps of Brawley and East Mesa KGRA's.5 


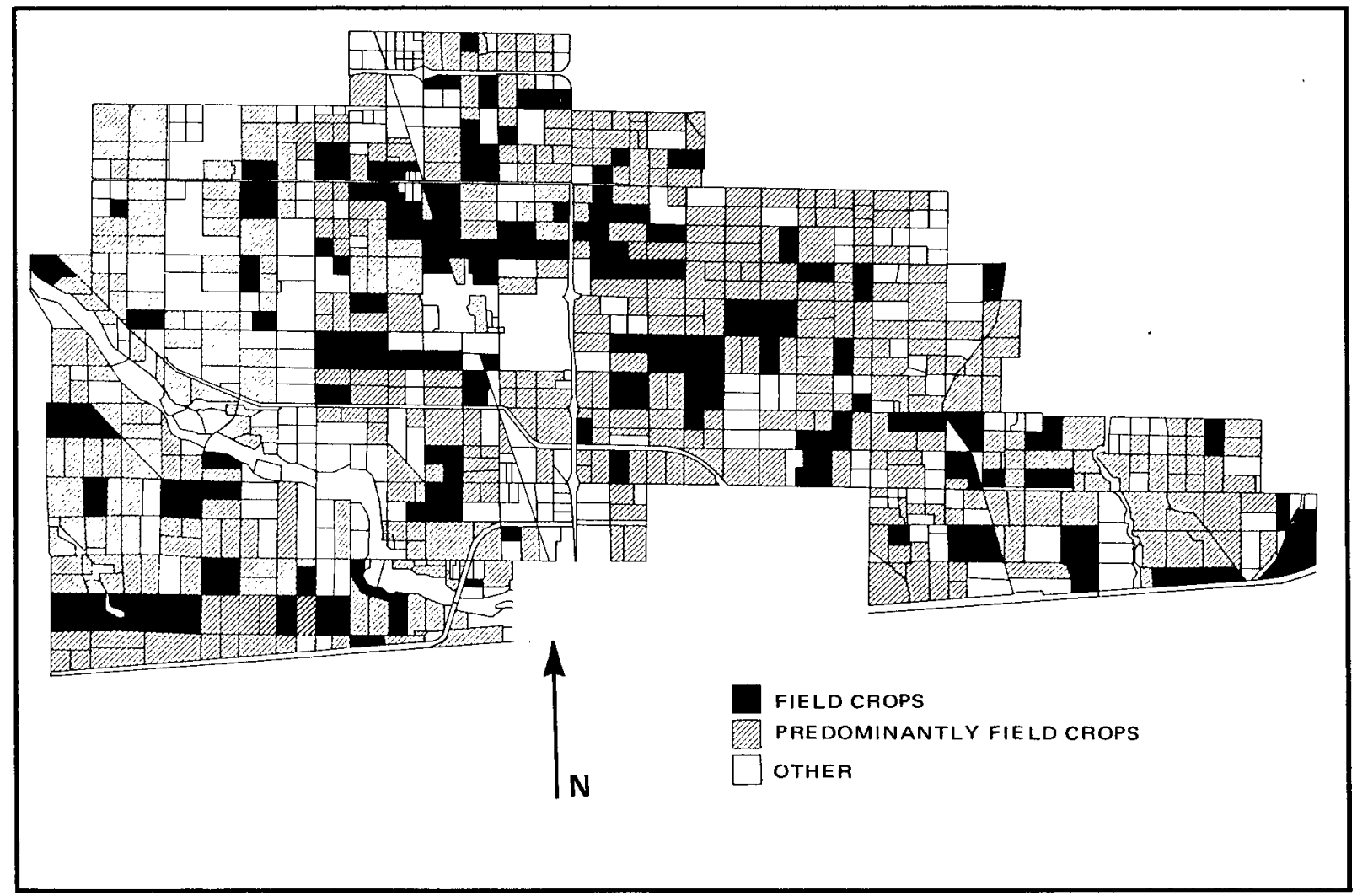

Fig. 4. Agricultural resource map of the Heber KGRA. ${ }^{5}$ 


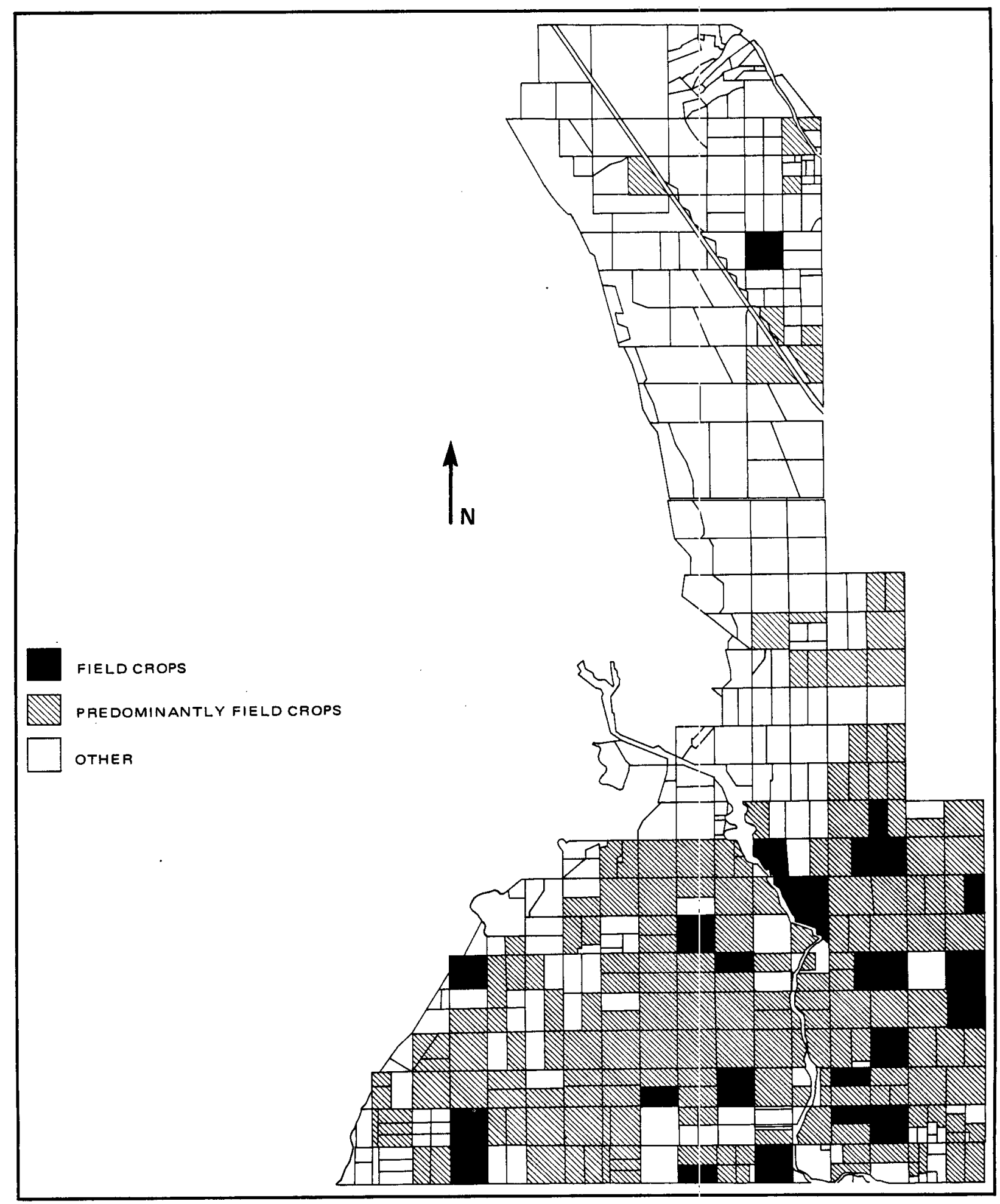

Fig. 5. Agricultural resource map of the Salton Sea KGRA. 5 
Table 1. Pesticide Usage in Imperial County in 1975.

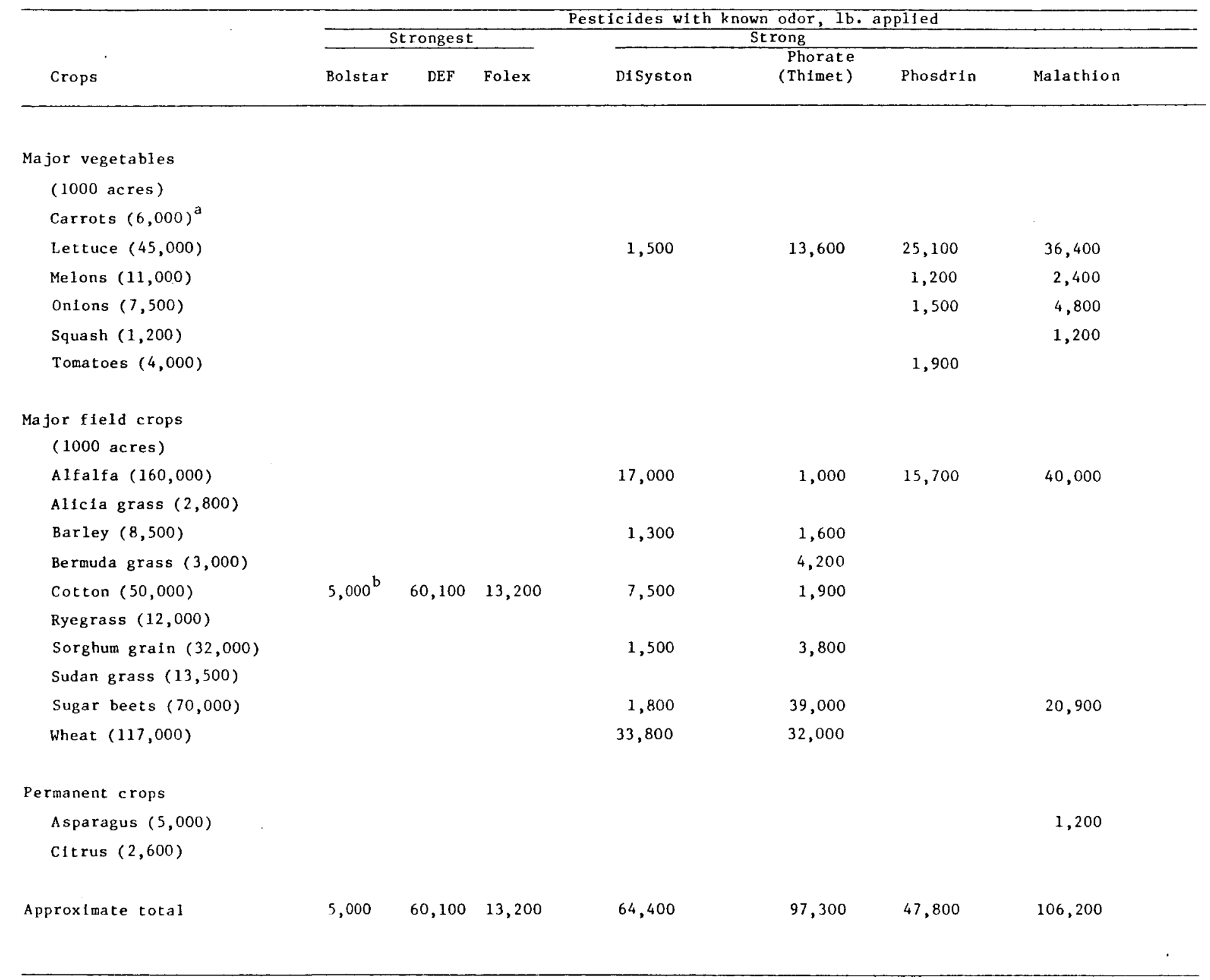

a Approximate average acreage in 1973-1975.

b Approximately 500 gal in $1978 .^{3}$ 
Table 1. (cont.) Pesticide Usage in Imperial County in 1975.

\begin{tabular}{|c|c|c|c|c|}
\hline \multirow[b]{2}{*}{ CROPS } & \multicolumn{4}{|c|}{ Pesticides similar to Malathion, lb. applied } \\
\hline & Betasan & Infdam & Demeton & Phosphalone \\
\hline \multicolumn{5}{|l|}{ Major vegetables } \\
\hline \multicolumn{5}{|l|}{$(1000$ acres $)$} \\
\hline \multicolumn{5}{|l|}{ Carrots $(6,000)^{a}$} \\
\hline Lettuce $(45,000)$ & 500 & & & \\
\hline Melons $(11,000)$ & 500 & & & \\
\hline \multicolumn{5}{|l|}{ Onions $(7,500)$} \\
\hline \multicolumn{5}{|l|}{ Squash $(1,200)$} \\
\hline Tomatoes $(4,000)$ & 2,400 & & 900 & \\
\hline \multicolumn{5}{|l|}{ Major field crops } \\
\hline \multicolumn{5}{|l|}{ (1000 acres) } \\
\hline Alfalfa $(160,000)$ & & 2,200 & & \\
\hline \multicolumn{5}{|l|}{ Allcia grass $(2,800)$} \\
\hline \multicolumn{5}{|l|}{ Barley $(8,500)$} \\
\hline \multicolumn{5}{|l|}{ Bermuda grass $(3,000)$} \\
\hline Cotton $(50,000)$ & & & 300 & \\
\hline \multicolumn{5}{|l|}{ Ryegrass $(12,000)$} \\
\hline \multicolumn{5}{|l|}{ Sorghum grain $(32,000)$} \\
\hline \multicolumn{5}{|l|}{ Sudan grass $(13,500)$} \\
\hline \multicolumn{5}{|l|}{ Sugar beets $(70,000)$} \\
\hline Wheat $(117,000)$ & & & 1,200 & \\
\hline \multicolumn{5}{|l|}{ Permanent crops } \\
\hline \multicolumn{5}{|l|}{ Asparagus $(5,000)$} \\
\hline C1trus $(2,600)$ & & & & 300 \\
\hline Approximate total & 3,400 & 2,200 & 2,600 & 300 \\
\hline
\end{tabular}

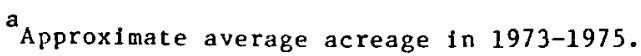


Table 1. (cont.) Pesticide Usage in Imperial County in 1975.

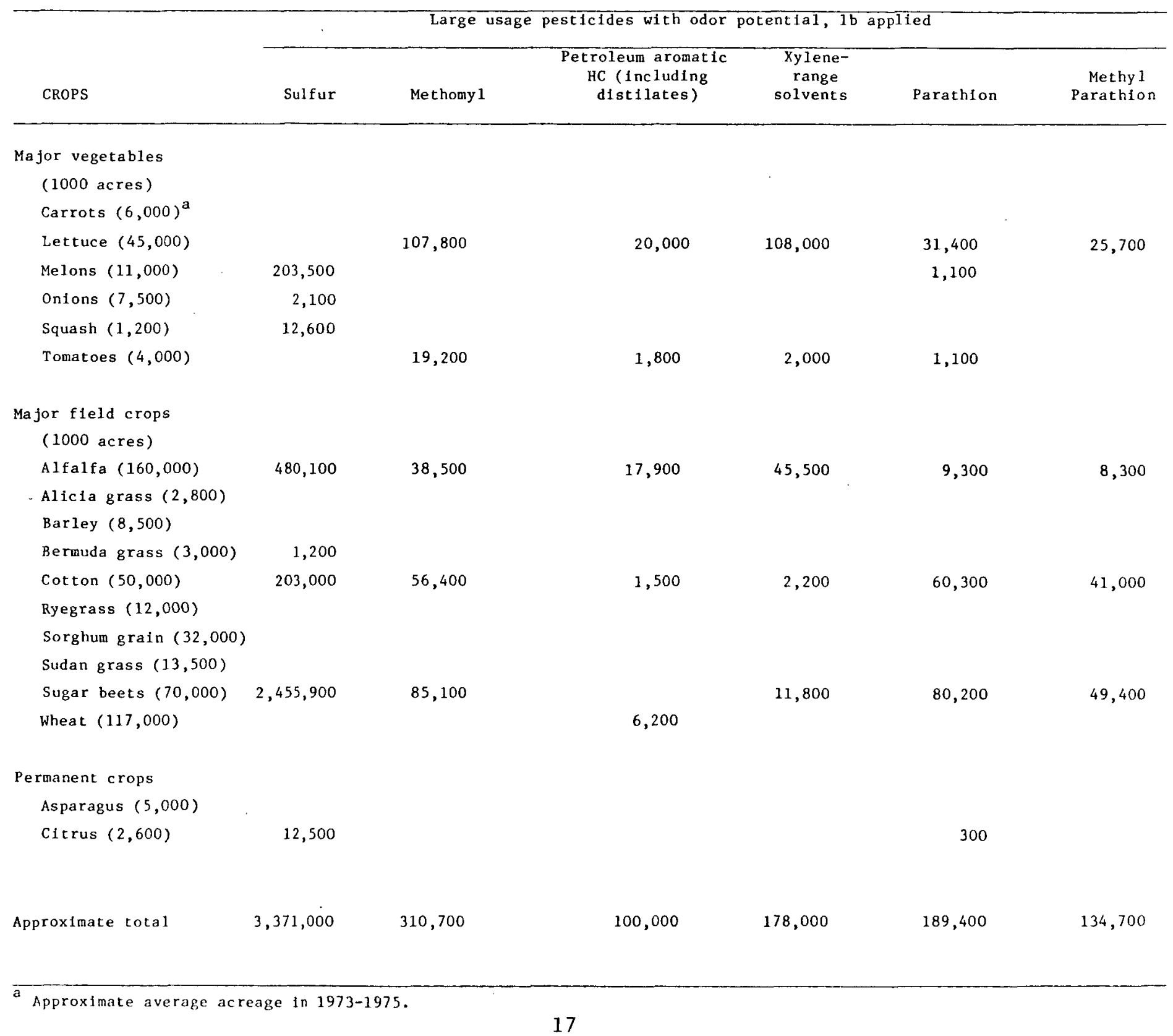


Agricultural Burning

Burning of agricultural residues in Imperial County is regulated under Imperial County Air Pollution Control District's Rules 701 to 706.

"Investigations are made of burns that do occur to determine if the responsible persons have obtained permits, and if burns are conducted in accordance with regulations. Violations or citations are issued to responsible persons violating these rules and regulations. "2

The Imperial County Air Pollution Control District has recently required that "...farmers burning agricultural wastes within one (1) mile of populated areas must obtain a special burning permit and allowed to burn only when smoke drift is away from these areas. Farmers are also required to disc burned fields within 48 hours to minimize fly ash blowing into residential areas. Burning is not permitted on 'No-Burn days.' 'Burn and No-Burn days' are established by ARB daily and notice issued daily to local farmers by the APCD. " 2

Also,

"Changes in the varieties of wheat in the last few years to shorter varieties has decreased the tonnage burnt. In 1976 mostly durham varieties were grown and consisted of $90 \%$ of the acreage. Since that time due to demand and prices hard red wheats are grown on $90 \%$ of the acreage. Due to the demand worldwide and developing markets in China this situation should not change.

"Although alternatives to burning are in the early stage of development, it is expected that in the future economically feasible practices will be developed. There is currently in the planning stage a plan to utilize crop residue to produce electricity in the District." ${ }^{2}$ Recently, some asparagus residues were cut and baled for use as a feedlot ration. 
Agricultural burning contributes $3.5 \%$ of the hydrocarbons emissions in Imperial County, and unknown amounts of particulate matter, $\mathrm{CO}$, and odor.

\section{FEEDLOTS}

Feedlots are an odor source that needs a historical introduction. Interest and concern about feedlots in Imperial County dates back to 1962 when both fly production and dust control were investigated. ${ }^{7,8}$ Again in 1967,8 dust control methods were evaluated. In 1969, airborne manure was considered as a possible contributing factor ${ }^{9}$ to the documented increased rates of hyperbilirubinemia among newborn infants during the fourth quarter of each of the four consecutive years $(1963-1966) \cdot{ }^{10}$ In 1971 , as a result of a resolution from the City of Calexico, ${ }^{11}$ a study of the potential health and nuisance problems from air pollution by dust and odor from cattle feedlots in Imperial county was completed. The recommendations called for a locally led, integrated approach. ${ }^{9}$ Since cattle feedlots were exempted from the Imperial County Air Pollution Control District's Regulations ${ }^{12}$ in 1971, local control was not possible until the regulations were amended to include a rule for livestock feed yards within 1.5 miles from any "urban limit" - Rule $420 .^{13}$ This rule only applies to dust control and thus will not eliminate all odors. Now, with this study, cattle feedlots again are of interest as contributing to odor and annoyance in Imperial County.

The location 3,14 and size 14 of the 67 active and inactive cattle feedlots in Imperial County are shown in Fig. 6. The feedlots are listed in Table 2. A bio-gas plant at one of the feedlots will attempt to convert the manure to methane economically with the residue being converted into a nutritious feed supplement for livestock as a by-product. If successful, the odors from feedlots will be reduced, as immediate removal of the manure reduces the time for odor transport. 


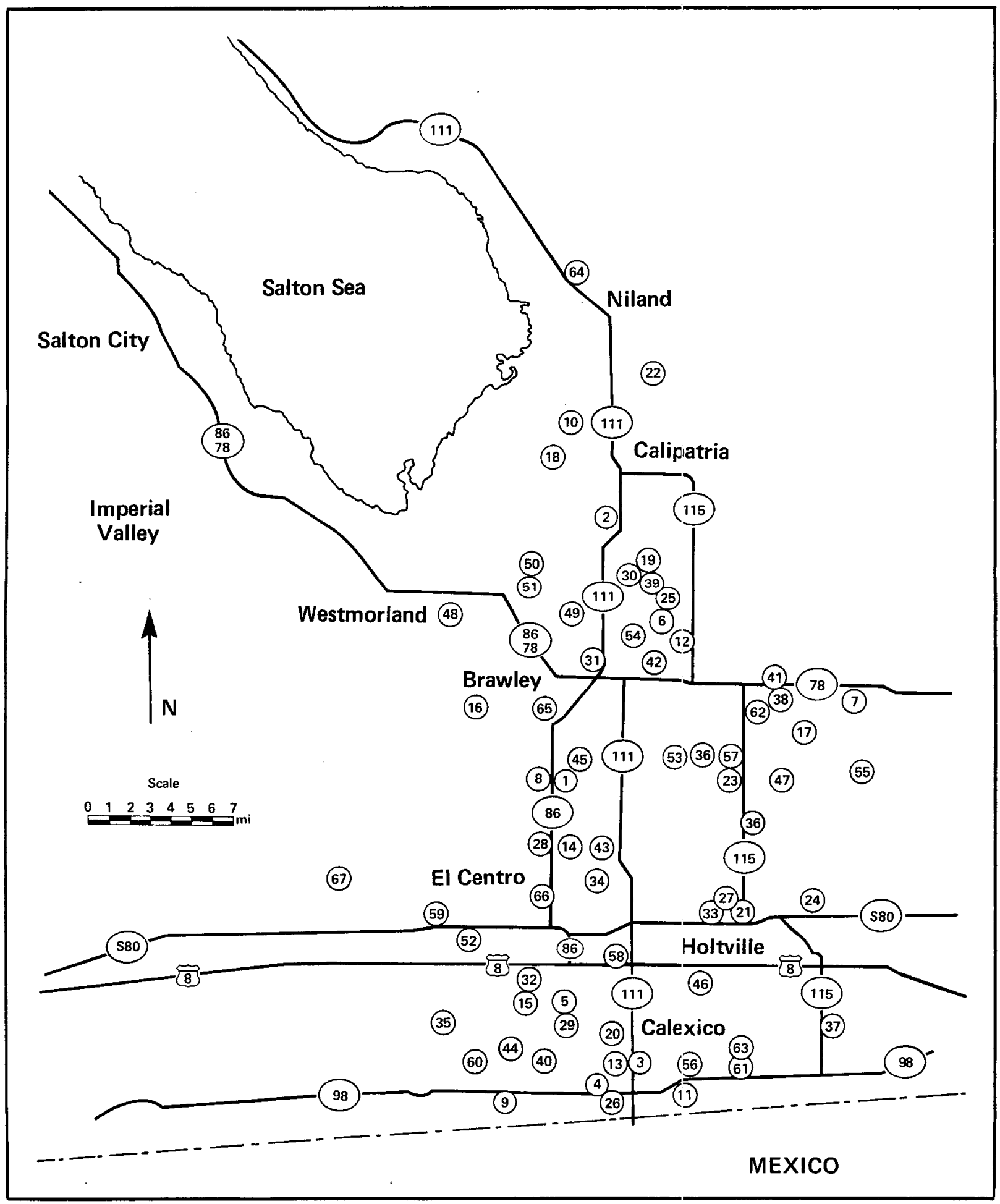

Fig. 6. Active and inactive feedlots in the Imperial Valley.Feedlots are numbered according to the list in Table 2. 
Table 2. Feedlots in Imperial County.

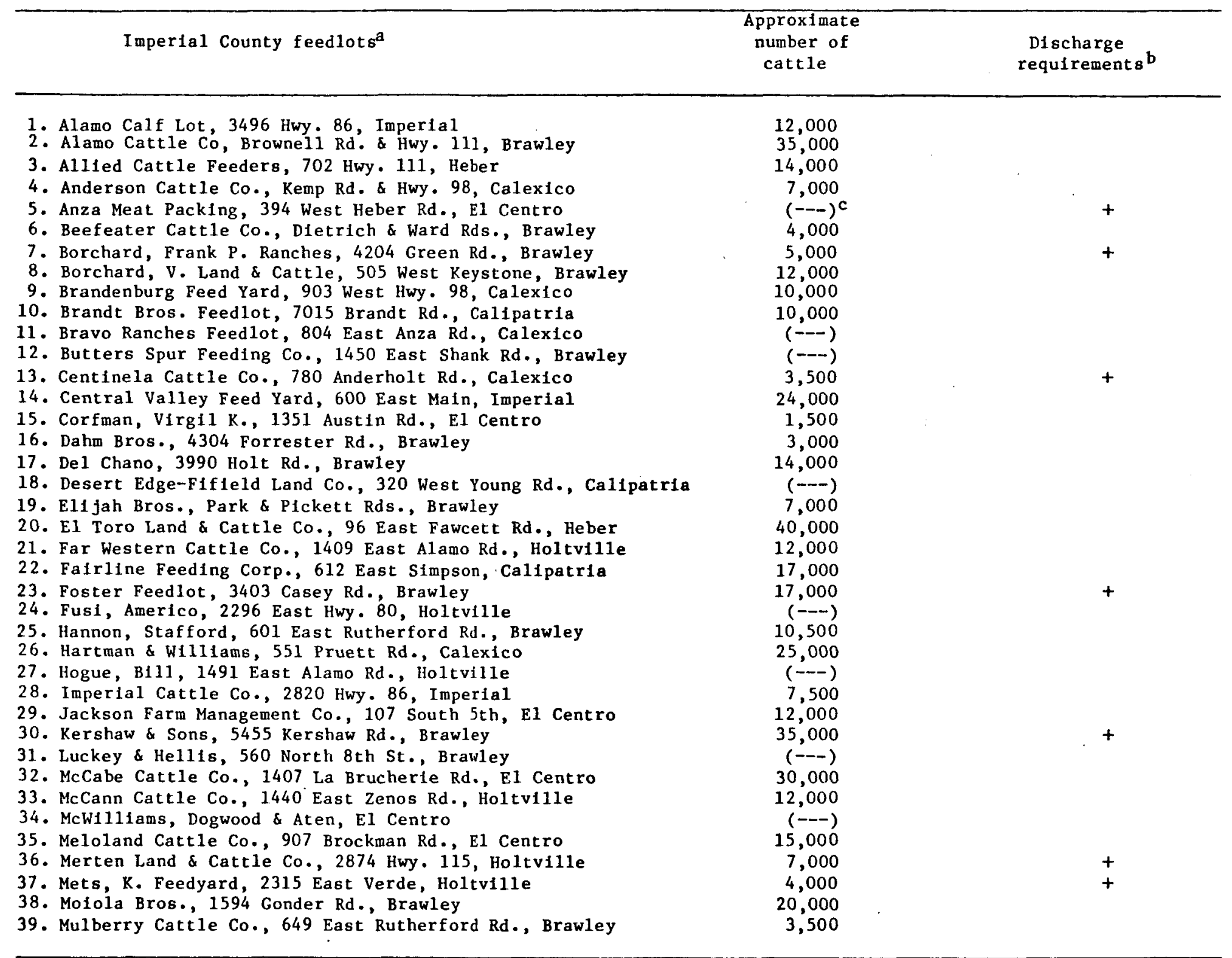

a Compiled from listings from Imperial County Agricultural Commissioner, Imperial Valley Bio-Gas Project, and Imperial County Telephone Directory.

b Colorado River Basin Reglonal Water Quality Control Board.

c Inact Ive or unknown, (--). 
Table 2. (cont) Feedlots in Imperial County.

\begin{tabular}{|c|c|c|}
\hline Imperial County feedlots $s^{a}$ & $\begin{array}{c}\text { Approximate } \\
\text { number of } \\
\text { cattle }\end{array}$ & $\begin{array}{c}\text { Discharge } \\
\text { Requirements }\end{array}$ \\
\hline 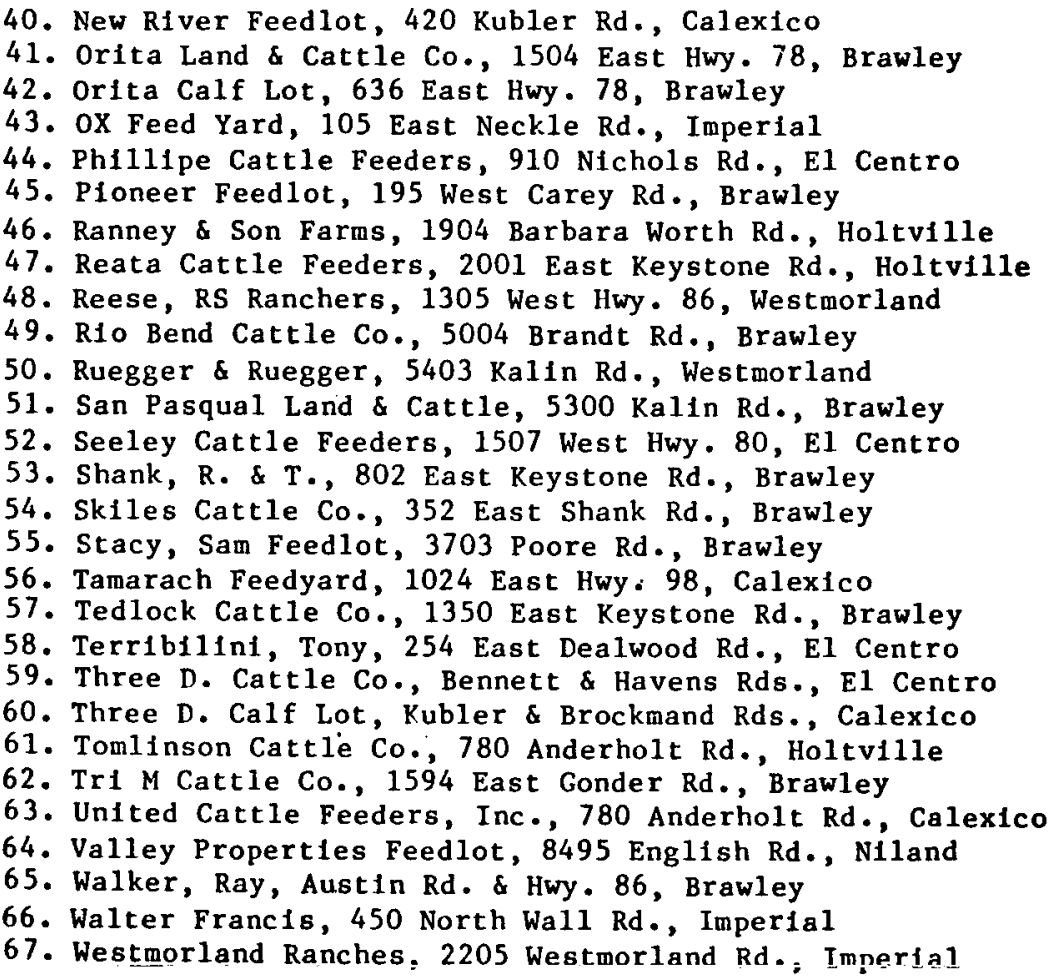 & $\begin{array}{r}12,000 \\
50,000 \\
3,000 \\
3,500 \\
20,000 \\
15,000 \\
(---)^{c} \\
5,000 \\
2,500 \\
12,000 \\
4,000 \\
15,000 \\
10,000 \\
(---) \\
9,000 \\
(---) \\
7,000 \\
12,000 \\
(---) \\
25,000 \\
25,000 \\
(---) \\
(---) \\
14,000 \\
(---) \\
15,000 \\
(---) \\
9,000\end{array}$ & $\begin{array}{l}+ \\
+\end{array}$ \\
\hline
\end{tabular}

a Complled from 11 stings from Imperial County Agricultural Commissioner, Imperial Valley Bio-Gas Project, and

Imperial County Telephone Directory.
c Colorado River Basin Regional Water Quality Control Board.
Inactive or unknown, (--). 
The odor from cattle feedlots emanates in two ways: ${ }^{15}$ First, as typical odor from fresh excreta, which is dissipated rapidly as the excrement cools and is not offensive, and second, as the highly odorous products of putrefaction of wet manure by bacteria. This anaerobic decomposition occurs when the percentage of moisture or degree of compaction is great enough to exclude atmospheric oxygen from the bacteriologically decomposing waste. ${ }^{16}$ However, if aerobic conditions exist, the highly odorous products are not formed. The first odor is not transported to any extent, but the second odor is transported substantial distances and in two forms, volatile materials and dust. Volatile materials are a combination of many organic and inorganic chemicals; Table 3 lists the cited chemicals from cattle waste. ${ }^{16-18}$

Dust from cattle feedlots can be distinguished from other blowing dust. 19 The dust ranges in size from large particles to aerosols and will carry the odors from the feedlots to the surrounding area.

The distance that the feedlot odor can be transported depends upon many factors. Air stability, temperature, and wind speed are important as well as feedlot size and dust-control techniques. Imperial County officials ${ }^{3}$ feel that at dusk when the cattle move around and an inversion exists with little ( 3 to $4 \mathrm{mph}$ ) or no air movement, the odor can be transported as far as one mile. Others ${ }^{16}$ support the concept of a buffer zone in the shape of an egg with the axis from 4 to 20 miles. The identifiable feedlot dust may actually travel more than the 750 -meter limit reported, ${ }^{19}$ because substantial air mixing occurred and transport conditions were not optimum during that dust collection. 20 
Table 3. Volatile chemicals from cattle wiste.16-18

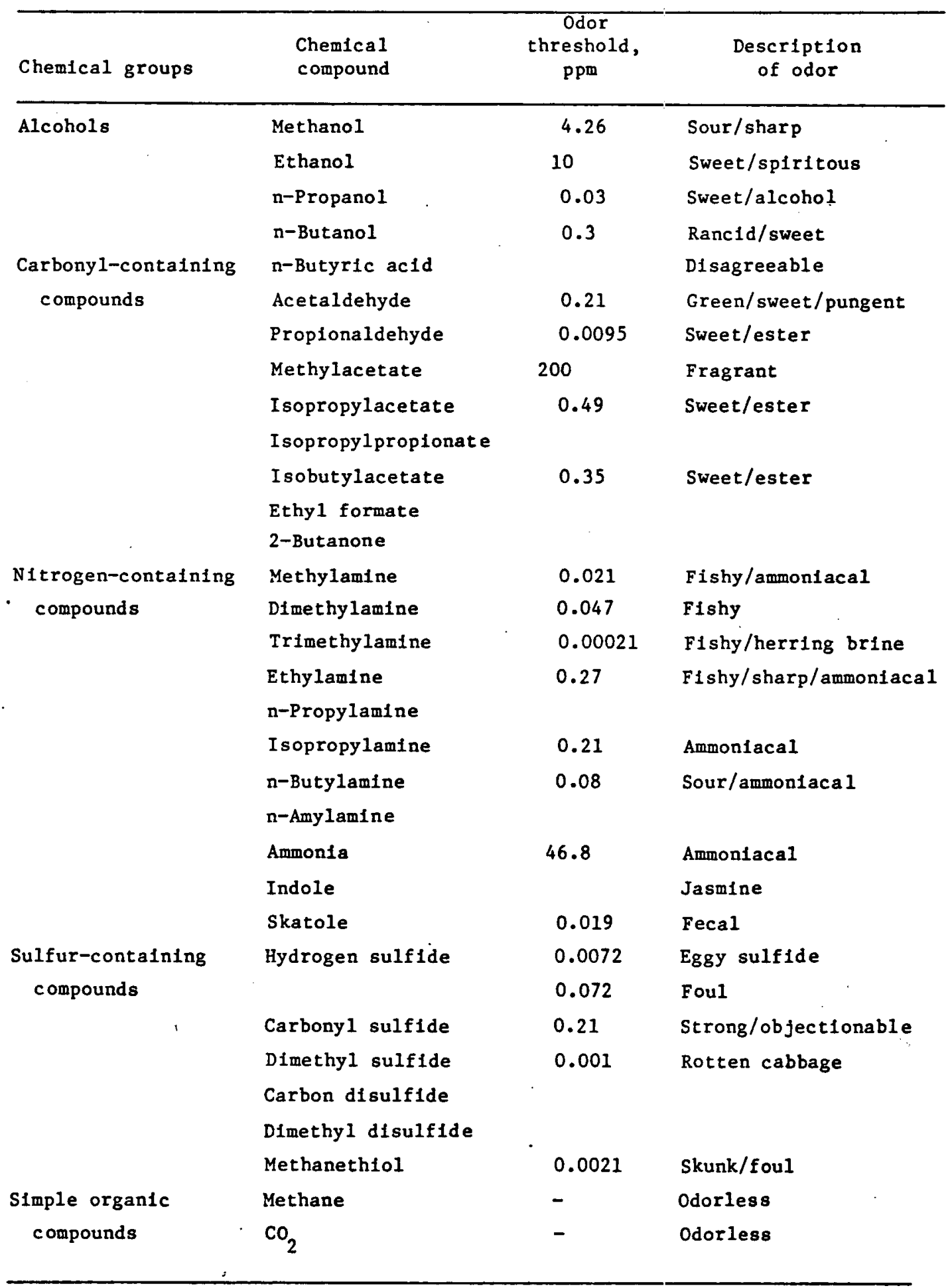


OTHER STATIONARY SOURCES OF ODOR

Odors from stationary sources are produced only in well defined areas. The following discussion lists these sources of odor in detail. Ten types of stationary sources can cause odors in Imperial County:

- A rendering plant,

- Sewage treatment plants,

- Landfills,

o Fertilizer manufacturing and distributing plants,

- Alfalfa dehydration plants,

- A sugar processing plant,

- Cotton ginning plants,

- Power plants,

- Asphalt batching plants,

- Existing geothermal wells and experimental power plants.

Al1 of these sources are shown in Fig. 7, except for the geothermal wells, which are shown in the next section in Figs. 8 and 9. 


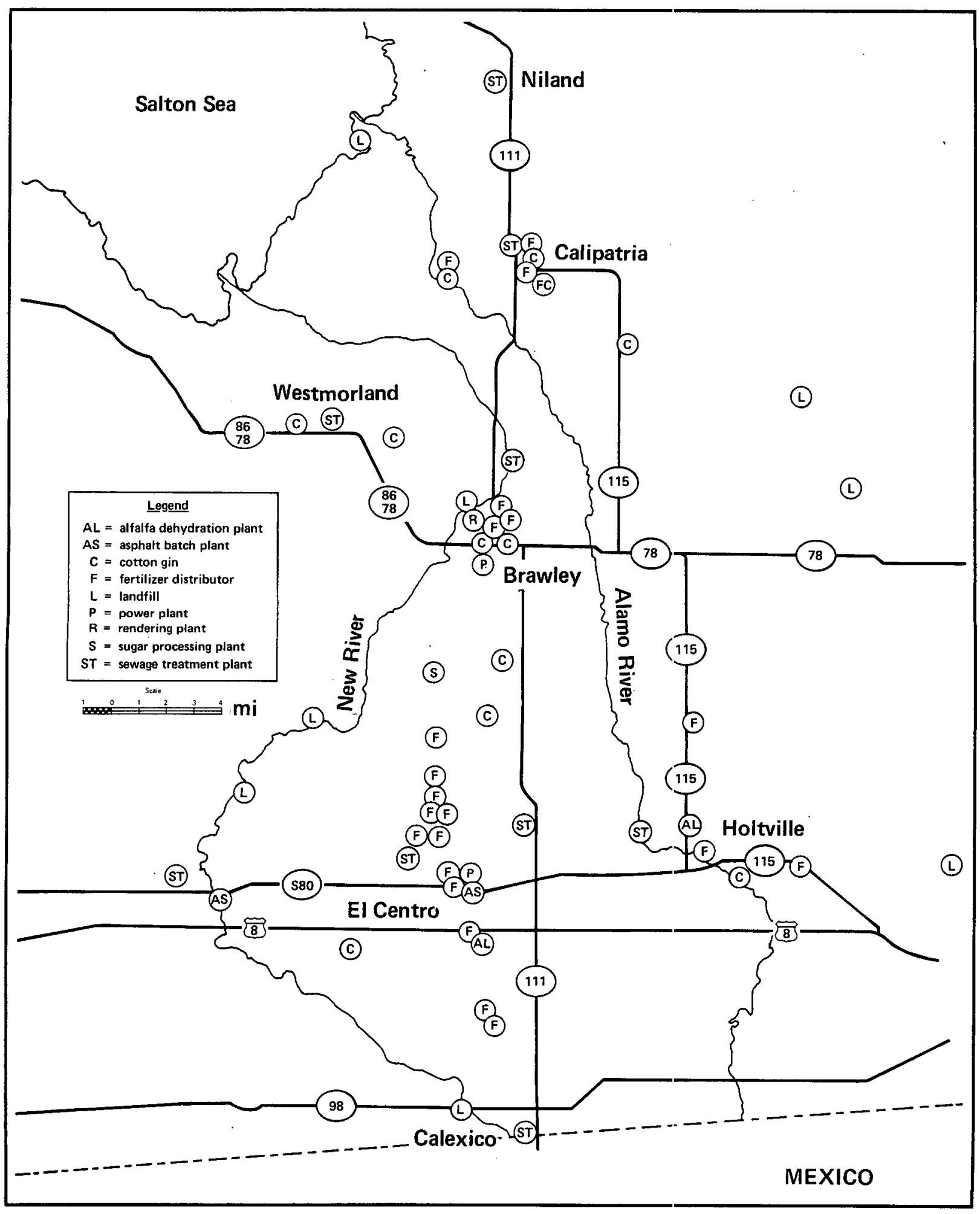

Fig. 7. Stationary sources of odor in the Imperial Valley with the exception of feedlots, which are given in Fig. 6 . 
Rendering Plant

The rendering plant is Peterson Manufacturing, 4750 Hoveley Road, Brawley. In 1972, strong odor emanated from the process waste. ${ }^{21}$ The odorants identified in rendering plant emissions are listed in Table $4 .^{17,18,22}$ The areal extent of perceptible odor ${ }^{23}$ from rendering plants is an average of $0.8 \mathrm{mi}^{2}$ with a range of 0.2 to $1.3 \mathrm{mi}^{2}$.

Table 4. Odorants in rendering plant emissions. $17,18,22$

\begin{tabular}{|c|c|c|c|}
\hline $\begin{array}{l}\text { Chemical } \\
\text { group }\end{array}$ & $\begin{array}{l}\text { Chemical } \\
\text { compound }\end{array}$ & $\begin{array}{l}\text { Odor } \\
\text { threshold, } \\
\text { ppm }\end{array}$ & Description \\
\hline Sulfides & $\begin{array}{l}\text { n-Propyl sulfide } \\
\text { Dimethyl sulfide } \\
\text { Propylene sulfide }\end{array}$ & $\begin{array}{l}0.001 \\
22.5\end{array}$ & $\begin{array}{l}\text { Rotten cabbage } \\
\text { Aromatic }\end{array}$ \\
\hline Amines & $\begin{array}{l}\text { Trimethylamine } \\
\text { Tert-buty lamine } \\
\text { n-Butylamine } \\
\text { Dimethyl pyrazine } \\
\text { Quinoline }\end{array}$ & $\begin{array}{l}0.00021 \\
0.08\end{array}$ & $\begin{array}{l}\text { Fishy, herring brine } \\
\text { Sour/ammoniacal }\end{array}$ \\
\hline Acids & Butyric & & Disagreeable \\
\hline Aldehydes & $\begin{array}{l}\text { n-Pentanal } \\
\text { (Valeraldehyde) }\end{array}$ & & \\
\hline Alcohols & $\begin{array}{l}\text { n-Pentanol } \\
\text { (n-Amyl alcohol) }\end{array}$ & 0.21 & Sweet/alcohol \\
\hline Ketones & $\begin{array}{l}\text { Butanedione } \\
\text { (Diacety1) }\end{array}$ & & \\
\hline $\begin{array}{l}\text { Unsaturated } \\
\text { alkanes }\end{array}$ & $\begin{array}{l}\text { Heptadiene } 2,5 \\
\text { (Simulant for } \\
\text { dimethyl pentadiene) }\end{array}$ & & \\
\hline
\end{tabular}


Sewage-Treatment P1ants

Odors are possible from the nine sewage-treatment plants in Imperial

Valley, as well as the continuing problem of raw sewage contamination in the New River from Mexicali, Mexico. ${ }^{24}$ Table 5 contains a list of

sewage-treatment plants.

Table 5. Sewage-treatment plants in Imperial Valley.
Plant
Size

(Design average daily flow, mgd ${ }^{a}$ )

1) City of Calexico

1.7

298 E. Anza Road, Calexico

2) City of E1 Centro

5.0

2255 La Brucherie Road, E1 Centro

0.42

3) City of Holtville

1250 E. Kamm Road, Holtville

2.65

4) City of Brawley

5015 Best Road, Brawley

5) City of Westmorland

0.25

5295 Martin Road, Westmorland

0.30

6) Niland Sanitary District

P. O. Box 1348, Niland

7) City of Calipatria

101 N. Lake Street, Calipatria

0.30

8) City of Seeley

0.13

P. O. Box 161, Seeley

9) Imperial Community College District

0.15

P. 0. Box 158, Imperial

a Million gal/da. 
Complaints have been made of odor from $\mathrm{H}_{2} \mathrm{~S}$ in the northwest section of El Centro from the City of El Centro's sewage treatment plant. ${ }^{3}$ These complaints may have been made when the sewage was treated in lagoons. The Colorado River Basin Regional Water Quality Control Board in Palm Desert has had no complaints in the last 3 to 4 years since advanced secondary treatment began at the $\mathrm{E} 1$ Centro Sewage Treatment Plant. ${ }^{25}$ The City of Brawley has ponds for its treated sewage, and odors have been associated with the ponds. ${ }^{26}$ The areal extent of perceptible odor ${ }^{23}$ from sewage treatment plants is an average of $2.5 \mathrm{mi}^{2}$.

Landfills

There are eleven landfills in the Imperial Valley. They are listed in Table 6 .

Complaints of odors, dust, noise, and biological vectors are common from landfills. The transportation of odors, etc. from landfills greatly depends on their size and operation. The areal extent of perceptible odor will be assumed to be between that of feedlots and sewage treatment plants.

\section{Fertilizer Manufacturing}

One major fertilizer (ammonia) manufacturing plant is located in the Imperial Valley: Valley Nitrogen Producers Inc., 50 West Danenbert Road, EI Centro. When leaks of ammonia occur, many complaints are made. For example, an ammonia spill occurred on October 22,1978 , when an operator broke a pipe nipple on an active ammonia line. ${ }^{27}$ The areal extent of perceptible odor ${ }^{23}$ of agricultural chemical plants is an average of $6 \mathrm{mi}^{2}$. Besides the large manufacturing plant, there are 8 wholesale distributors and 14 retail distributors of fertilizers where leaks from loading could occur. These additional sources are listed in Table 7 . 
Table 6. Landfills in the Imperial Valley.

Location
Amount received, tons/year

Calexico - Imperial County Number 2

$2-1 / 2 \mathrm{mi}$ west of Calexico on Highway 98

16,000

Ocotillo - Imperial County Number 5

2-1/2 mi north of Ocotillo off Shell Canyon Road

$$
1,000
$$

Holtville - Imperial County Number 7

Near Holtville Airstrip

$$
2,000
$$

Brawley - Imperial County Number 9

$1 \mathrm{mi}$ north of Brawley on Hovley Road

20,000

Niland - Imperial County Number 10

Between Coachella Canal and E. Highline Canal on Ciff Road

1,200

Niland Marina - Imperial County Number 11

North of Niland Marina

5,000

Imperial - Imperial County Number 18

6-1/2 mi west of Imperial on Worthington Road

6,000

Red Hill Marina - Imperia1 County Number 19

Near Red Hill

Magnolia - Imperial County Number 22

15 mi east of Brawley

$40,000^{a}$

Standard - Imperial County Number 23

$5 \mathrm{mi}$ northwest of Imperial

$2,000^{\mathrm{a}}$

Thompson Crossing - Imperial County Number 24

$5 \mathrm{mi}$ northwest of Imperial

$2,000,000^{a}$

a Cubic yards/year. 
Table 7. Wholesale and retail fertilizer distributors in the Imperial Valley.

\begin{tabular}{|c|c|c|}
\hline City & Wholesale distributors & Retail distributors \\
\hline \multirow[t]{4}{*}{ Brawley } & $\begin{array}{l}\text { Brawley Fertilizer Company } \\
4720 \text { Highway } 111\end{array}$ & $\begin{array}{l}\text { Brawley Fertilizer Company } \\
4720 \text { Highway } 111\end{array}$ \\
\hline & & $\begin{array}{l}\text { Imperial Grain Growers Bulk } \\
\text { Fertilizer Warehouse } \\
560 \text { North } 8 \text { th Street }\end{array}$ \\
\hline & & Pure Gro Company \\
\hline & & 1025 Adler Street \\
\hline \multirow[t]{2}{*}{ Calipatria } & $\begin{array}{l}\text { Dune Co. of the Imperial } \\
\text { Valley - } 340 \mathrm{E} \text {. Main }\end{array}$ & $\begin{array}{l}\text { Alamo Chemical Company } \\
6494 \text { Brandt Road }\end{array}$ \\
\hline & $\begin{array}{l}\text { Drewry Chemical Company } \\
409 \text { South Industrial Ave. }\end{array}$ & $\begin{array}{l}\text { Calipatria Farm Enterprises Inc. } \\
290 \text { East Young Road }\end{array}$ \\
\hline \multirow[t]{3}{*}{ E1 Centro } & $\begin{array}{l}\text { Agriform of Imperial Valley } \\
2375 \text { Clark Road }\end{array}$ & $\begin{array}{l}\text { Agriform of Imperial Valley } \\
2375 \text { Clark Road }\end{array}$ \\
\hline & $\begin{array}{l}\text { Chem-Ent, Inc. } \\
395 \text { Broadway }\end{array}$ & $\begin{array}{l}\mathrm{J} \& \mathrm{P} \text { Feed and Seed Company } \\
2393 \text { Highway } 86\end{array}$ \\
\hline & & $\begin{array}{l}\text { Axler Spreading } \\
95 \text { East Highway } 80\end{array}$ \\
\hline \multirow[t]{2}{*}{ Heber } & & $\begin{array}{l}\text { Agricultural Products Supply Co. } \\
\text { Highway } 86 \text { and Railroad }\end{array}$ \\
\hline & & $\begin{array}{l}\text { Brea Agricultural Service } \\
89 \text { East Main Street }\end{array}$ \\
\hline \multirow[t]{2}{*}{ Holtville } & $\begin{array}{l}\text { Agriform of Imperial Valley } \\
\text { Highway } 115 \text { and Harris Road }\end{array}$ & $\begin{array}{l}\text { Crown Chemical Company } \\
1548 \text { East Zenos Road }\end{array}$ \\
\hline & r & $\begin{array}{l}\text { Marini Spreaders } \\
2400 \text { East Highway } 80\end{array}$ \\
\hline \multirow[t]{2}{*}{ Imperial } & $\begin{array}{l}\text { Drewry Chemical Company } \\
506 \text { East 2nd Street }\end{array}$ & $\begin{array}{l}\text { Topham and Son, Inc. } \\
408 \text { East 2nd Street }\end{array}$ \\
\hline & $\begin{array}{l}\text { J.R. Simplot Company } \\
602 \text { North N Street }\end{array}$ & $\begin{array}{l}\text { Western Farm Service Inc. } \\
305 \text { West Larsen Road and } \\
\text { 2nd and N Streets }\end{array}$ \\
\hline
\end{tabular}




\section{Alfalfa Dehydration P1ants}

Two large alfalfa-dehydration mills are located in the Imperial Valley. They are Holtville Alfalfa Mills, Inc., 1504 East Kamm Road, Holtville, and United Alfalfa Mills, Inc., 45 West Danenberg Road, El Centro. Odors are emitted from these dehydration plants, and the areal extent of perceptible odor ${ }^{23}$ should be somewhat greater than granaries, which is $2 \mathrm{mi}^{2}$. Sugar Processing Plant

A large sugar-processing plant is located just south of Brawley at 395 West Keystone Road. This Holly Sugar Corporation plant operates seasonally (April through Ju1y); although the odor is distinctive and is transported beyond the plant, no official complaints have been made of odor. In 1974, a sweet odor from the sludge pond became strong and obnoxious as the sugar plant waste decomposed in the oxidation pond. ${ }^{28}$ The areal extent of perceptible odor ${ }^{23}$ will be assumed to be that of a granary, which is $2 \mathrm{mi}^{2}$. In the future, the plant may be using geothermal heat to process sugar in a direct application of geothermal energy - What $\mathrm{H}_{2} \mathrm{~S}$ emissions will occur remain to be seen; the study of this use of geothermal energy is a joint venture of the Holly Sugar Corporation and TRW Inc.

\section{Cotton-Ginning Plants}

Several cotton-ginning operations are located in Imperial Valley. Specific complaints of odor from the ginning process have not been received, although a substantial amount of particulate matter and dust is associated with cotton ginning. Also, the U.S. Environmental Protection Agency's (EPA) Carcinogen Assessment Group ${ }^{29}$ calculated that exposures to arsenic to a 
few people in close proximity to cotton gins resulted in a lifetime risk of respiratory cancer as high as $8.77 \times 10^{-3}$. The cotton ginning operations are

- Cal-Pat Growers, Inc.

420 North East Avenue, Calipatria,

- Church Borchard Murphy Gin Company

3410 Dogwood Road, Brawley,

- Grower's Brawley Gin

760 East Highway 78, Brawley,

- Grower's Orita Ginning Association

1295 East Highway 78, Brawley,

- Grower's Westmorland Gin

1304 West Highway 86, Westmorland,

- Imperial Cotton Products, Inc.

1520 Forrester Road, E1 Centro,

- Imperial Cotton Products

2151 Highway 115, Holtville,

- Planters Ginnery Company

Westmorland Gin

691 West Boarts Road, Westmorland,

Wiest Gin

5996 Highway 115, Calipatria,

- Imperial Farmers

West Eddins and Brant, Calipatria,

- Mid-Valley Ginnery Co.

296 E. Keystone Road, Brawley.

Also, a cotton-oil manufacturer is located in Calipatria: Producers

Cotton $0 i 1$ Company, 551 South Industrial Avenue.

The burning of cotton-gin waste or trash as agricultural waste is regulated under Imperial County Air Pollution Control District's Rule 703. Rule 703 expired on January 1, 1979, thus burning cotton trash 
will not be allowed in the future. Yet cotton trash has not been burned for the last several years; most of the cotton trash is dumped on unusable land near the Holly Sugar Plant off Dogwood Road, across the road from Holly Sugar's geothermal well. The remainder is fed to cattle. Specific complaints of odor or dust from the ginning waste have not occurred. The areal extent of perceptible odor ${ }^{23}$ (including dust) should be somewhat less than granaries, which is $2 \mathrm{mi}^{2}$.

\section{Power Plants}

The areal extent of perceptible odor ${ }^{23}$ for electricity generation is an average of $1.7 \mathrm{mi}^{2}$. A $180-\mathrm{MW}$ power plant operated by the Imperial Irrigation Nistrict is located at $485 \mathrm{E}$. Villa Avenue, E1 Centro. A 20-MW-peaking plant is operated by the Imperial Irrigation District at 750 South Imperial Avenue, Brawley. The 180-MW plant is gas- or oil-fired, while the 20-MW plant is a gas turbine run on diesel fuel.

The City of E1 Centro may be using geothermal fluids for direct application of geothermal energy in the near future. Potential $\mathrm{H}_{2} \mathrm{~S}$ emissions from this developing system cannot be determined at present. There are two wells, one for production and one for reinjection; the Community Center will be heated from this federally supported project. Asphalt-Batching Plants

Two asphalt-batching plants are located in the Imperial Valley:

- Wm. H. Raley Company 1859 W. Highway 80 , Seeley,

- Massey Sand and Rock 51 E. Main, E1 Centro.

The areal extent of perceptible odor ${ }^{23}$ should be close to that of a general chemical plant, which is an average of $5 \mathrm{mi}^{2}$ with a range of 0.6 to $8.4 \mathrm{mi}^{2}$. 


\section{Geothermal Wells and Experimental Power Plants}

In the Imperial Valley the number of geothermal experimental units is ever increasing, including test wells, production wells, experimental separators, and small electrical generator units. These units are not the first in the Valley. Hot water wells were drilled east of the Alamo River 50 to 60 years ago, as well as the carbon dioxide plant that was located at the edge of the Salton Sea. All of the current operations contribute to odor emissions. Two geothermal power plant units have authority-toconstruct permits from the Imperial County Air Pollution Control District. One unit, the 13-MW Magma Power Company's binary cycle, is due to be completed in February 1979. The other, the 48-MW Republic Geothermal's flash cycle has not been started. The Union Oil Company has applied for an authority-to-construct permit and a 10-MW unit will soon be constructed in the Brawley KGRA. Chevron Resources expects to construct a 50-MW unit in the Heber KGRA in 1982. San Diego Gas \& Electric is operating a demonstration unit in the Salton Sea KGRA. Other experimental operations are located in the Salton Sea KGRA, including one that attempted to sell calcium chloride from the brine. There are 202 permitted exploratory and production wells in Imperial County; many more have not yet been drilled, but the discharge requirements from the Colorado River Basin Regional Water Quality Control Board have been issued. Odor from these developing units will be considered negligible at present.

Inventory of Emission Sources

Table 8 lists sources in the Imperial Valley emitting pollutants at a rate greater than 25 tons/year. 
Table 8. Emission source inventory, Imperial Valley.a

\begin{tabular}{|c|c|c|c|c|c|c|c|}
\hline \multirow[b]{2}{*}{ Source } & \multirow[b]{2}{*}{$\begin{array}{l}\text { S ICb } \\
\text { Code }\end{array}$} & \multicolumn{5}{|c|}{ Pollutants, tons,year } & \multirow{2}{*}{$\begin{array}{l}\text { No. } \\
\text { processes } \\
\text { No. emission } \\
\text { points }\end{array}$} \\
\hline & & Part & $\mathrm{SO}_{2}$ & $\mathrm{NO}_{2}$ & $\mathrm{HC}$ & $\mathrm{CO}$ & \\
\hline $\begin{array}{l}\text { Cal-Pat Growers } \\
420 \text { N. East Ave. } \\
\text { Calipatria }\end{array}$ & 0724 & 24 & - & - & - & - & $\frac{1}{1}$ \\
\hline $\begin{array}{l}\text { Church Borchard Murphy GIn } \\
3410 \text { Dogwood } \\
\text { Brawley }\end{array}$ & 0724 & 47 & - & - & - & - & $\frac{1}{1}$ \\
\hline $\begin{array}{l}\text { Growers Brawley Gin } \\
760 \mathrm{E} . \mathrm{Hwy} \cdot 78 \\
\text { Brawley }\end{array}$ & 0724 & 23 & - & 1 & - & - & $\frac{1}{2}$ \\
\hline $\begin{array}{l}\text { Growers Orita Gin } \\
1295 \text { E. Hwy } 78 \\
\text { Brawley }\end{array}$ & 0724 & 18 & - & 1 & - & - & $\frac{1}{2}$ \\
\hline $\begin{array}{l}\text { Growers Westmorland Gin } \\
1304 \mathrm{~W} \text {. Hwy } 86 \\
\text { Westmorland }\end{array}$ & 0724 & 31 & - & - & - & - & $\frac{1}{1}$ \\
\hline $\begin{array}{l}\text { Holly Sugar Company } \\
395 \mathrm{~W} \text {. Keystone Rd } \\
\text { Brawley }\end{array}$ & 2063 & 80 & 66 & 113 & 5 & 15 & $\frac{6}{12}$ \\
\hline $\begin{array}{l}\text { Holtville Alfalfa M1lls } \\
1504 \text { Kamm Rd } \\
\text { Holtville }\end{array}$ & 2048 & 82 & - & 12 & - & - & $\frac{5}{9}$ \\
\hline $\begin{array}{l}\text { Imperial Cotton Products } \\
1520 \text { Forester } \\
\text { E1 Centro }\end{array}$ & 0724 & 17 & - & - & - & - & $\frac{1}{2}$ \\
\hline $\begin{array}{l}\text { Imperial Cotton Products } \\
2151 \text { Hwy } 115 \\
\text { Holtville }\end{array}$ & 0724 & 15 & - & - & - & - & $\frac{1}{2}$ \\
\hline $\begin{array}{l}\text { Imperial Farmers } \\
\text { W. Eddins \& Brandt } \\
\text { Calfpatria }\end{array}$ & 0724 & 9 & - & - & - & - & $\frac{1}{2}$ \\
\hline $\begin{array}{l}\text { Imperial Irrigation District } \\
485 \mathrm{E} . \text { Villa Rd. } \\
\text { El Centro }\end{array}$ & 4911 & 182 & 3138 & 3470 & 42 & 98 & $\frac{4}{8}$ \\
\hline $\begin{array}{l}\text { Planters Cotton GIn } \\
691 \text { W. Boarts Rd. } \\
\text { Westmorland }\end{array}$ & 0724 & 59 & - & - & - & - & $\frac{1}{1}$ \\
\hline
\end{tabular}

a 25 tons/y; data from California Resources Board, Sacramento, Calif., 1977.

b Standard Industrial Classification. 
Table 8. (cont) Emission source Inventory, Imperial Valley.a

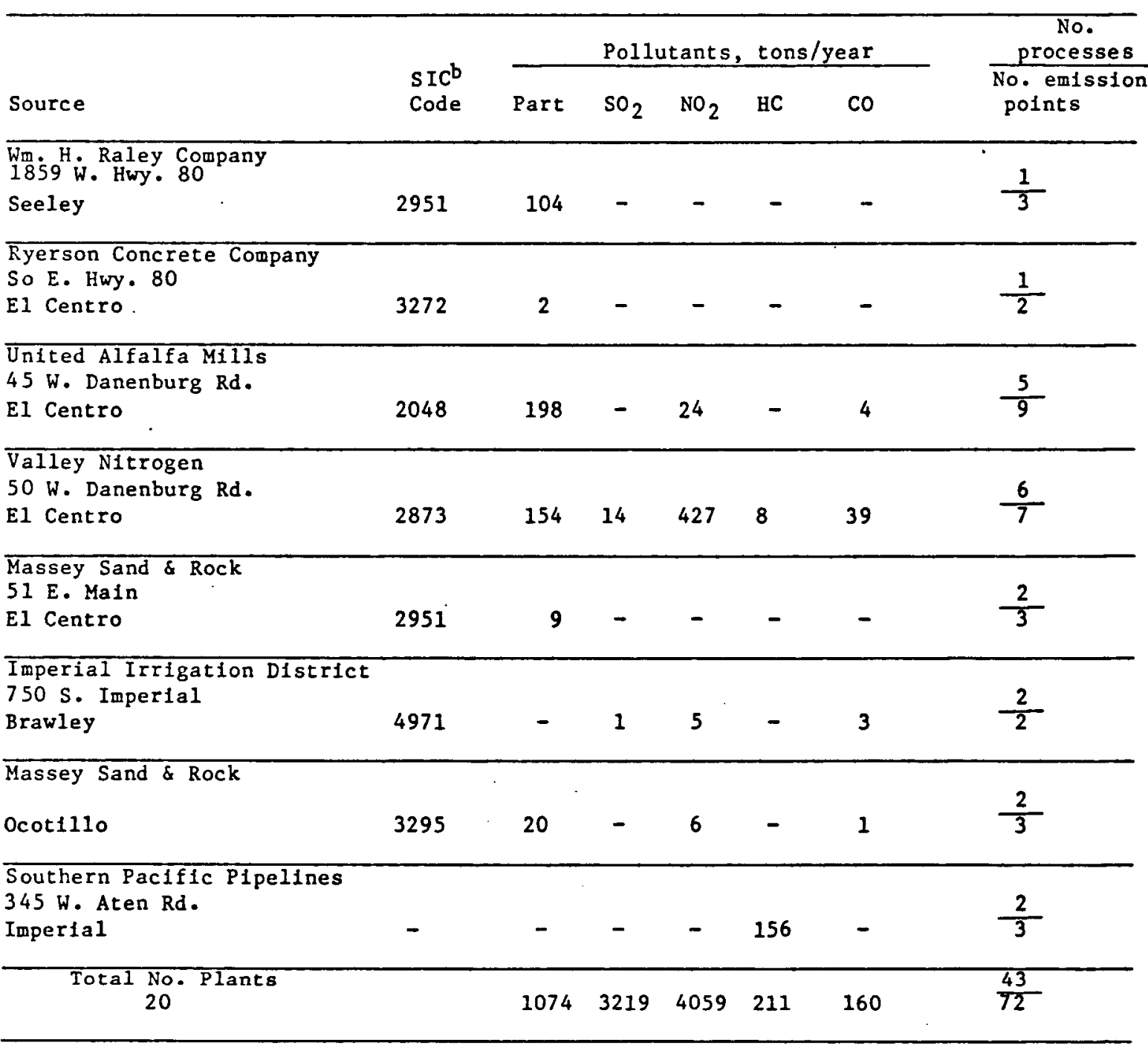

a 25 tons/y; data from California Resources Board, Sacramento, Cal1f., 1977.

b Standard Industrial Classification. 
ODOR SOURCE LOCATION AND MAPPING OF AREAS OF CIDOR PERCEPTION AND AFFECTED POPULATIONS

In this section, all odor sources described in the previous section are mapped. The mapping shows the odor sources and the areal extent of perceptible odor from these sources first on an Imperial Valley map and with more detail on seven other maps with the population centers in larger scale. Thus, in Figs. 8 through 16, all stationary scurces of odor and their areal extent of perceptible odor are mapped alorig with the affected populations . 


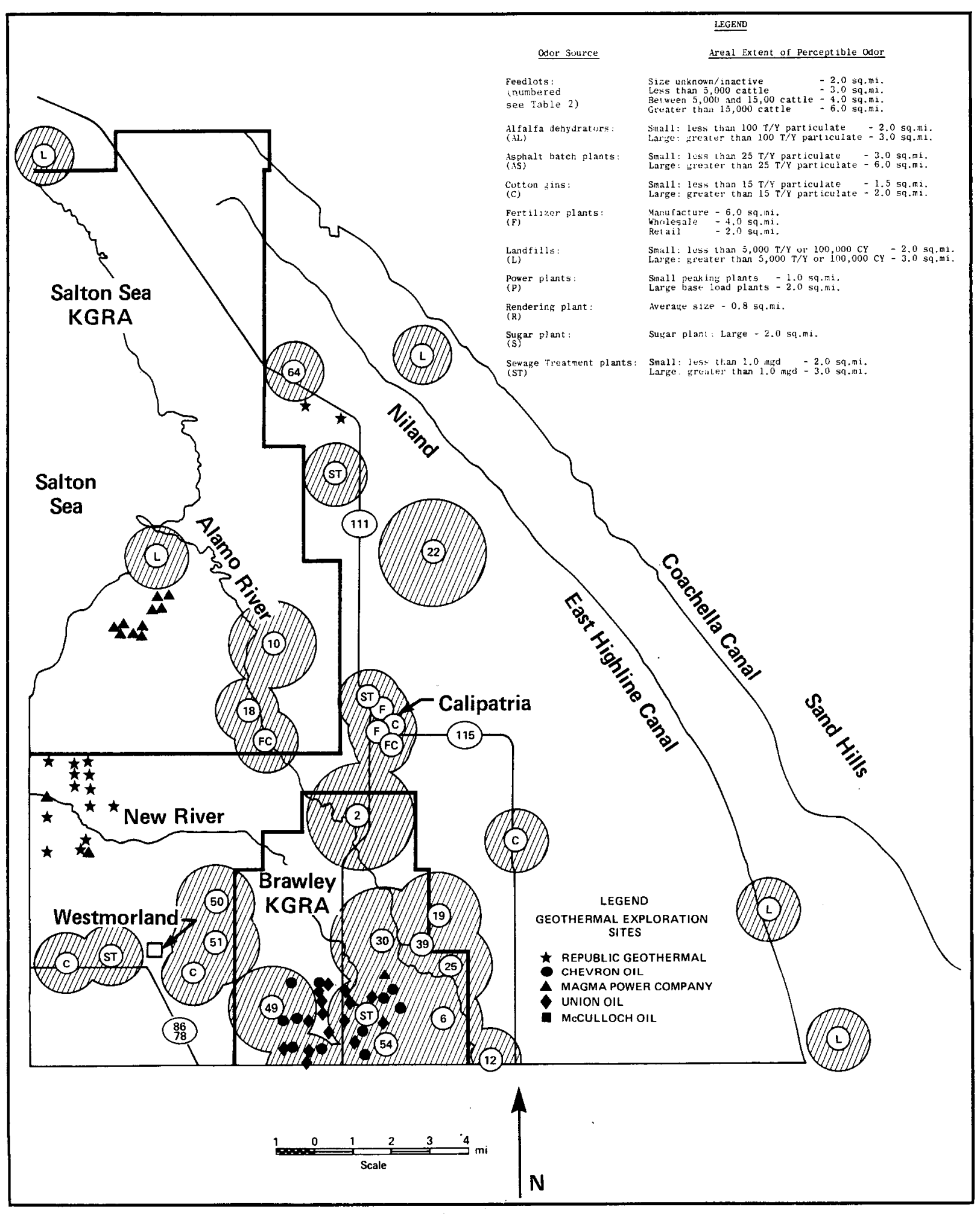

Fig. 8. Stationary sources of odor and the affected populations (hatched areas) in the northern half of Imperial Valley. 


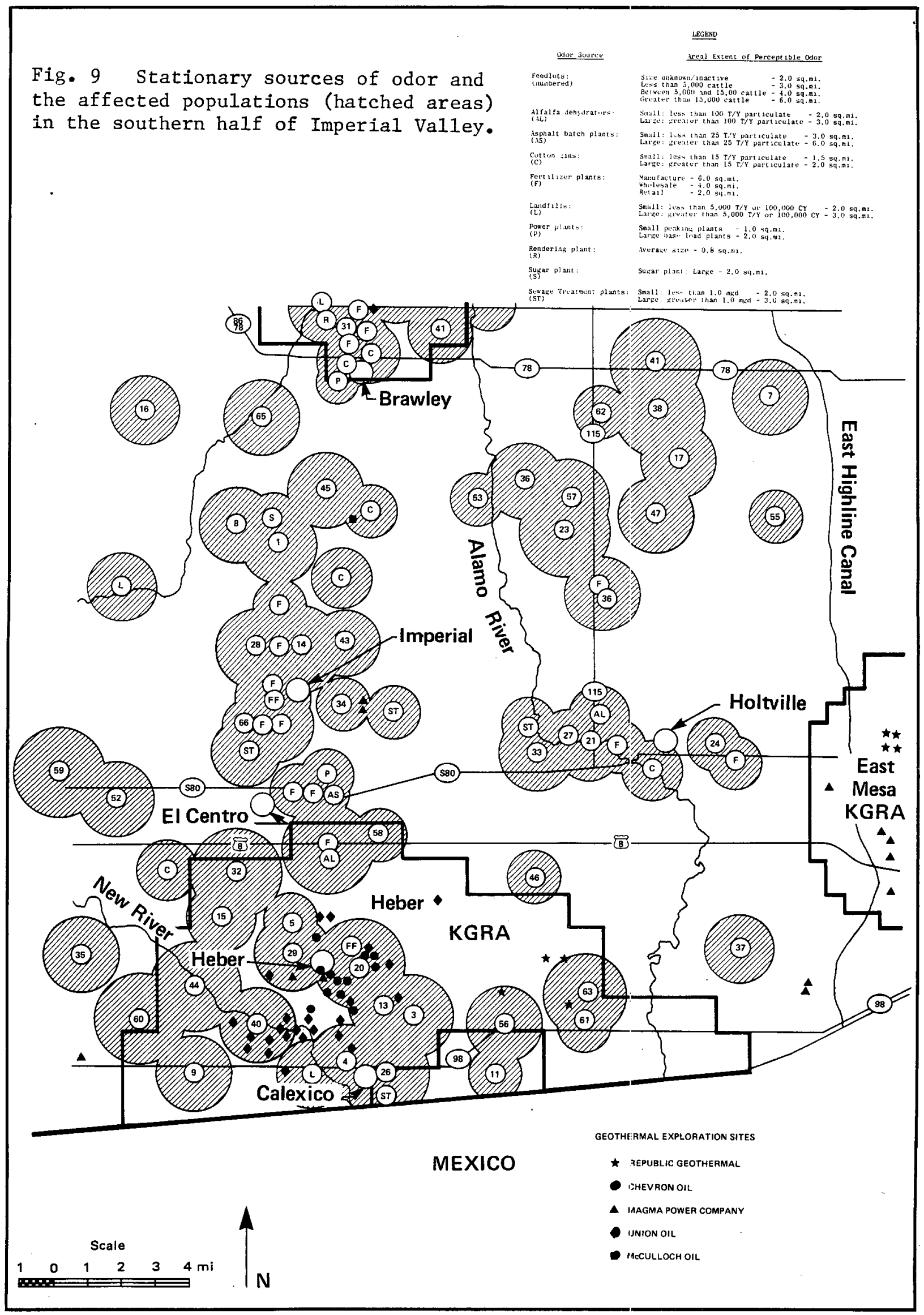




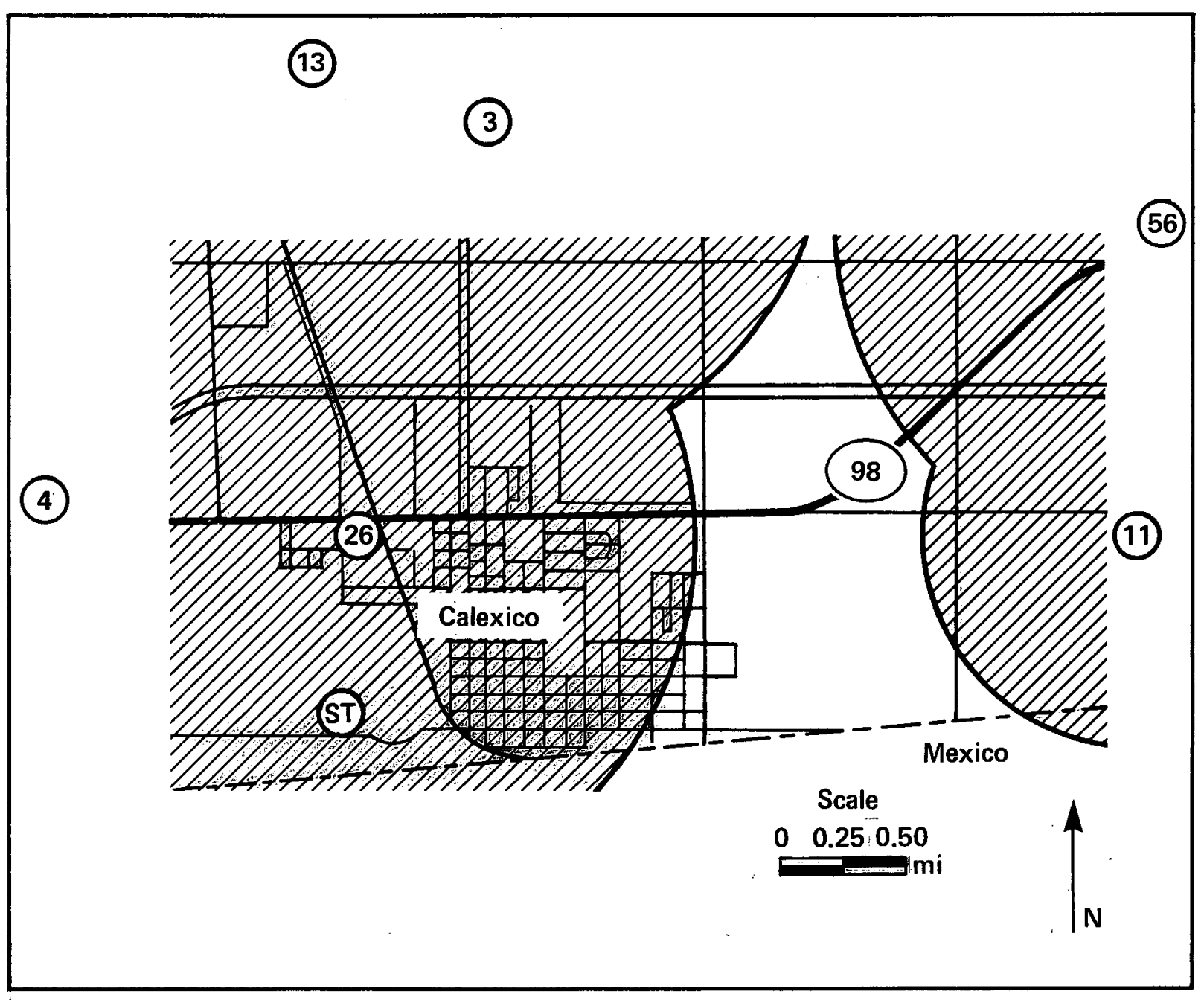

Fig. 10. Stationary sources of odor near Calexico (numbered feedlots listed in Table 2, ST = sewage treatment plant). Hatched areas are those affected by odor. 


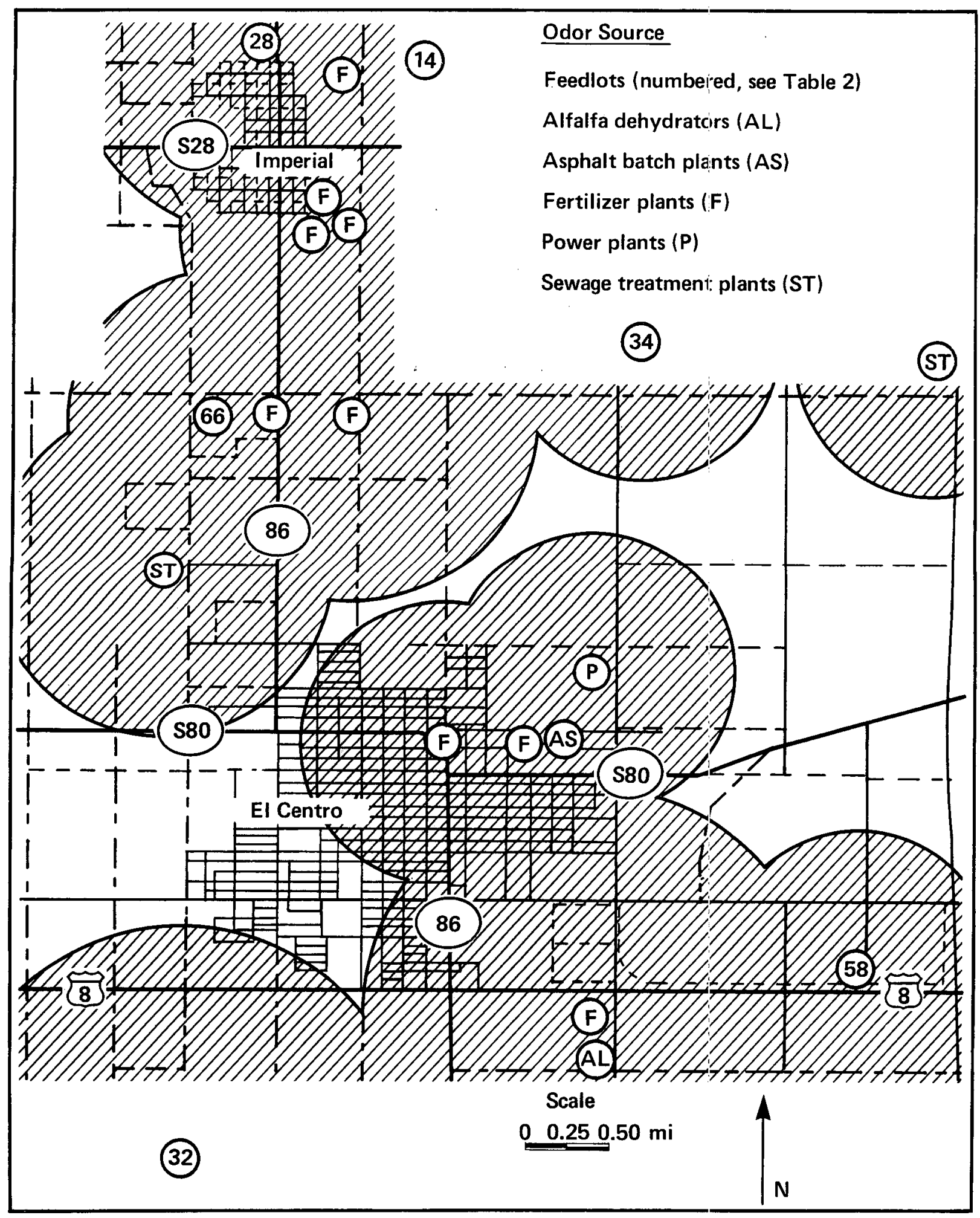

Fig. 11. Stationary sources of odor near Imperial and El Centro. Hatched areas are those affected by odor. 


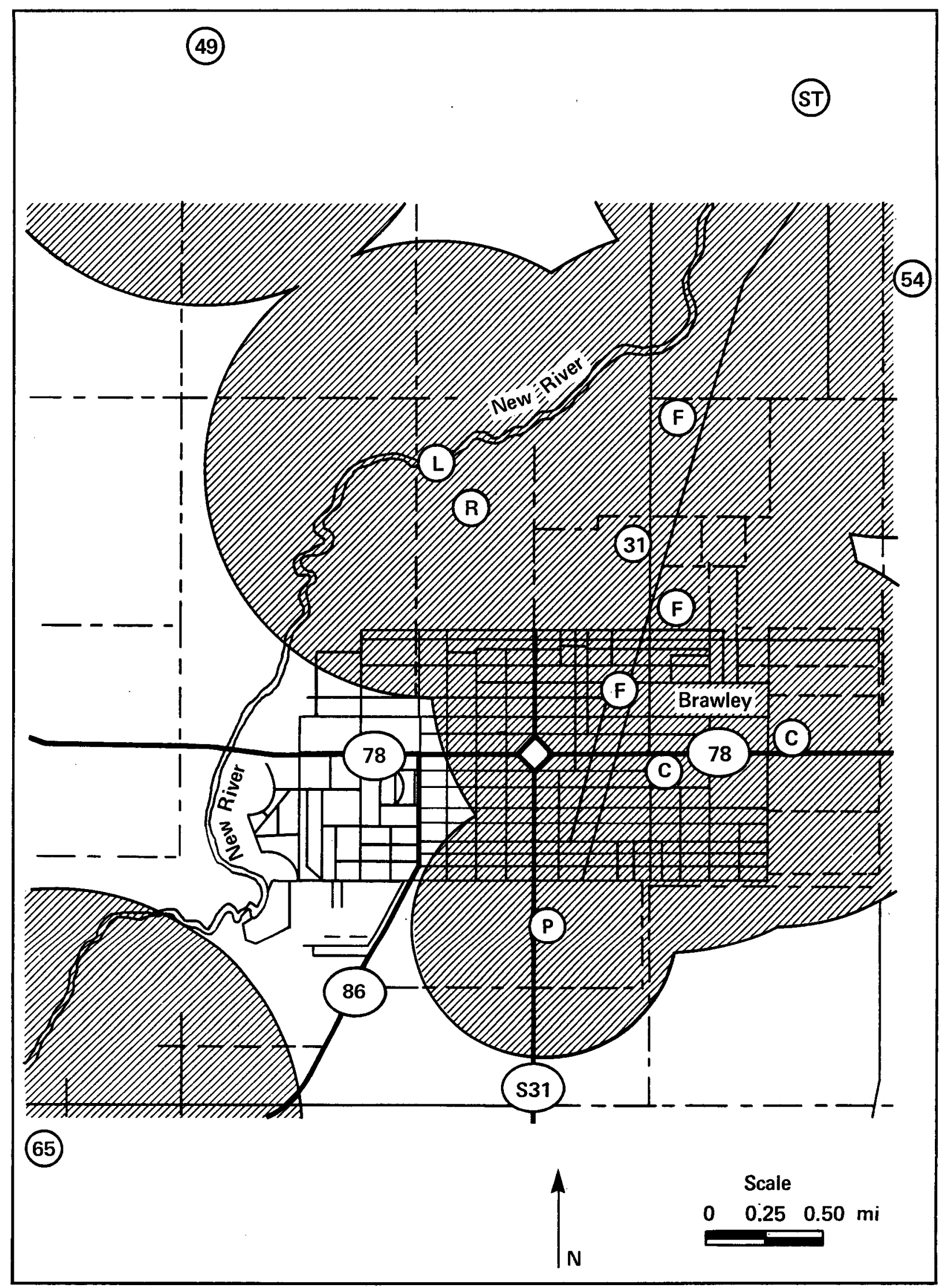

Fig. 12. Stationary sources of odor near Brawley (numberea feedlots listed in Table 2, $\mathrm{C}=$ cotton $\mathrm{gin}, \mathrm{F}=$ fertilizer plant, $\mathrm{L}=$ Ianafiil, $P=$ power plant, $R=$ rendering plant). Hatched areas are those affected by oāor. 


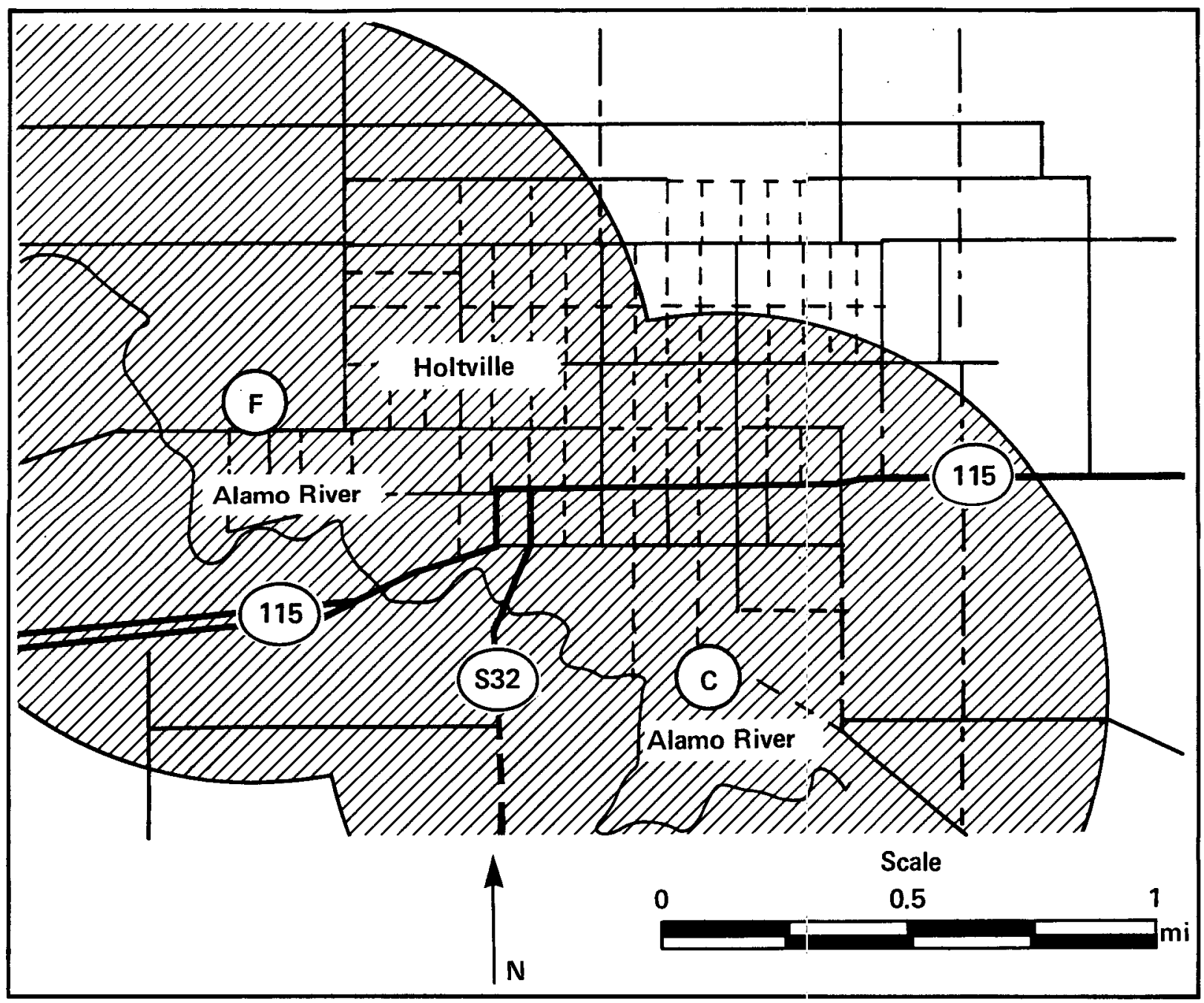

Fig. 13. Stationary sources of odor near Holtvilie $(C=$ cotton gin, $F=$ fertilizer plant). Hatched areas are those affected by odor. 


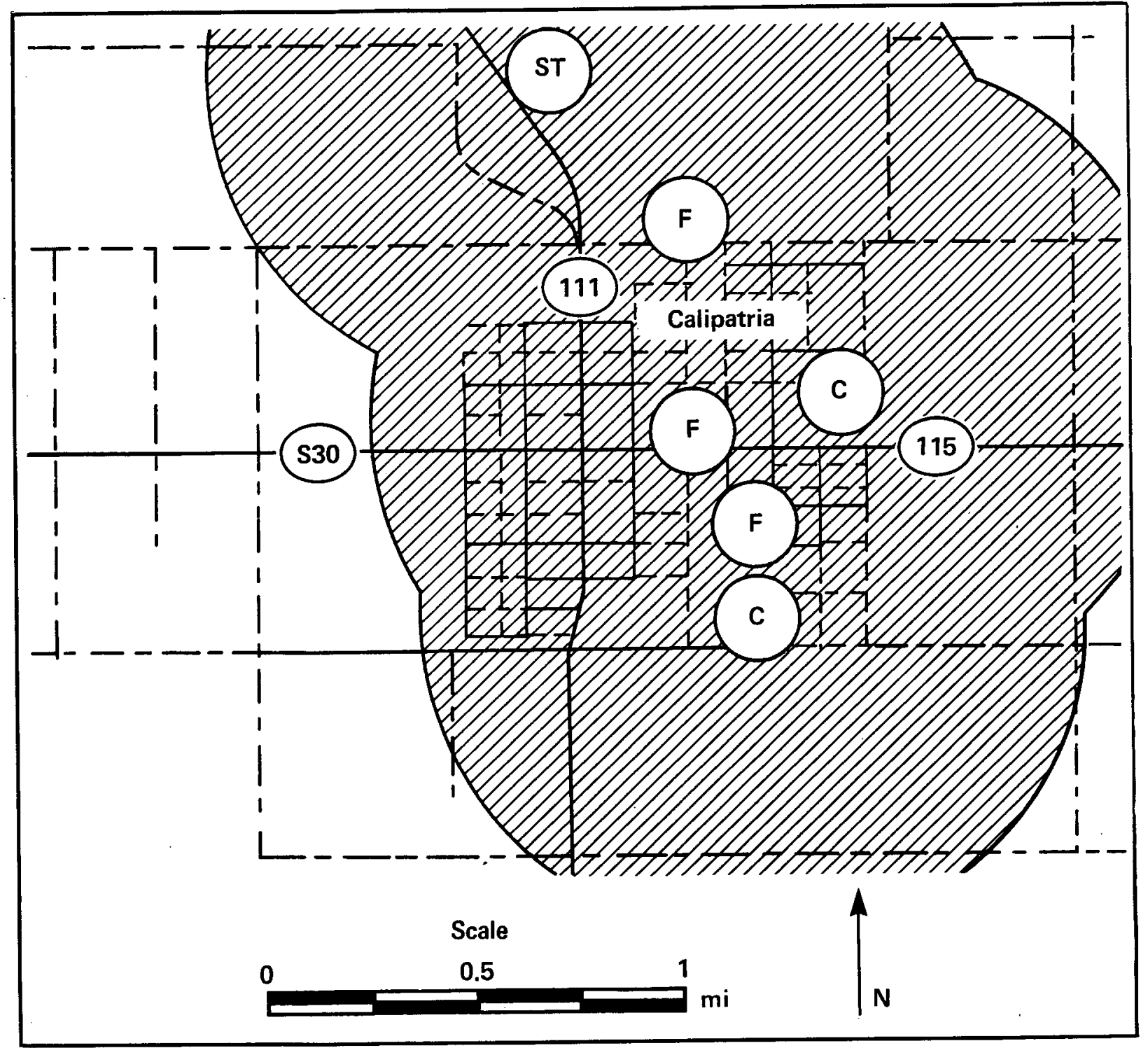

Fig. 14. Stationary sources of odor near Calipatria ( $C=$ cotton gin, $\overrightarrow{\mathrm{F}}=$ fertilizer plant, $\mathrm{ST}=$ sewage treatment plant). Hatched areas are those affected by odor. 


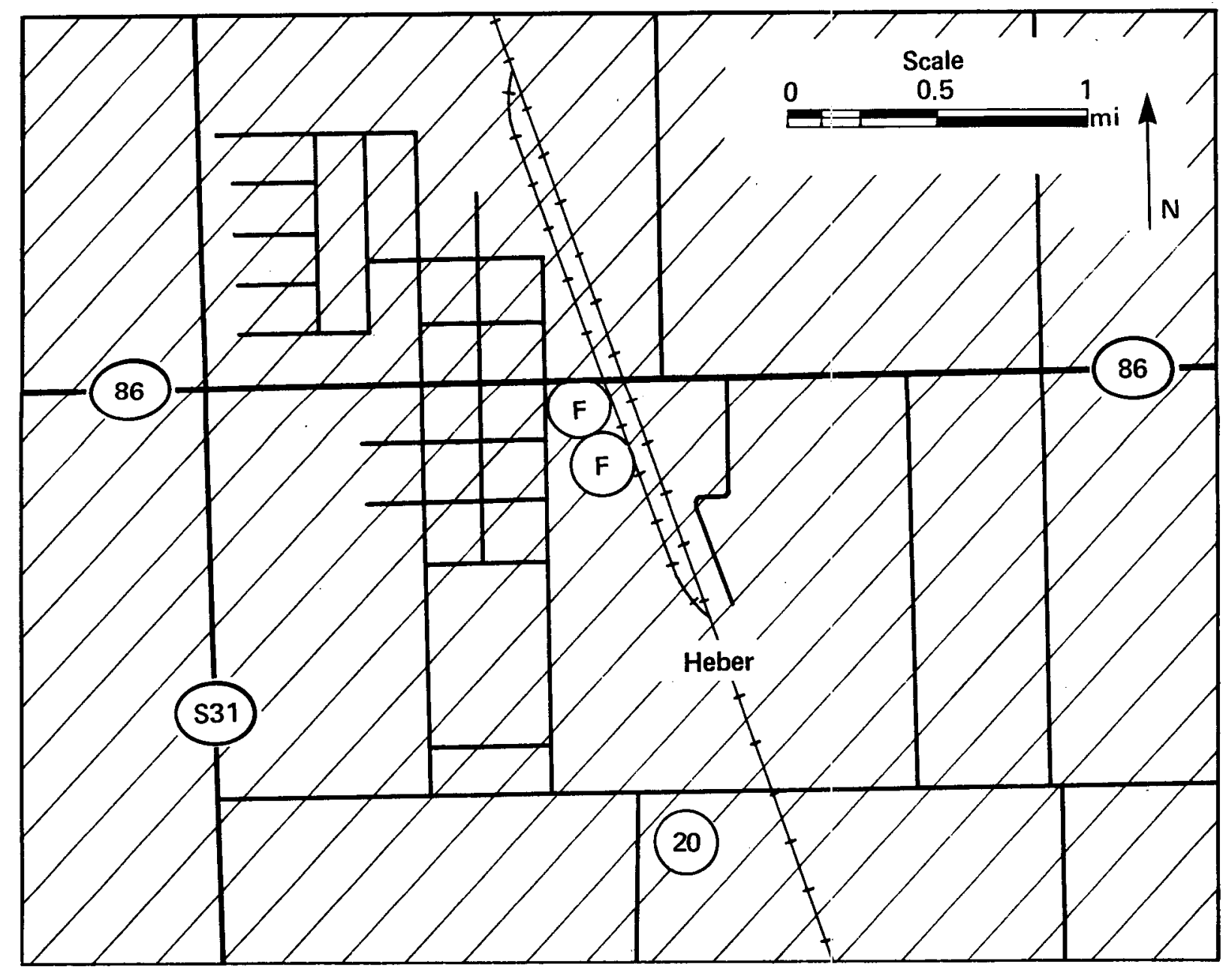

Fig. 15. Stationary sources of odor near Heber ( $F=$ fertilizer plant, numbered feedlot listed in Table 2). The entire area (hatched) is affected by odor. 


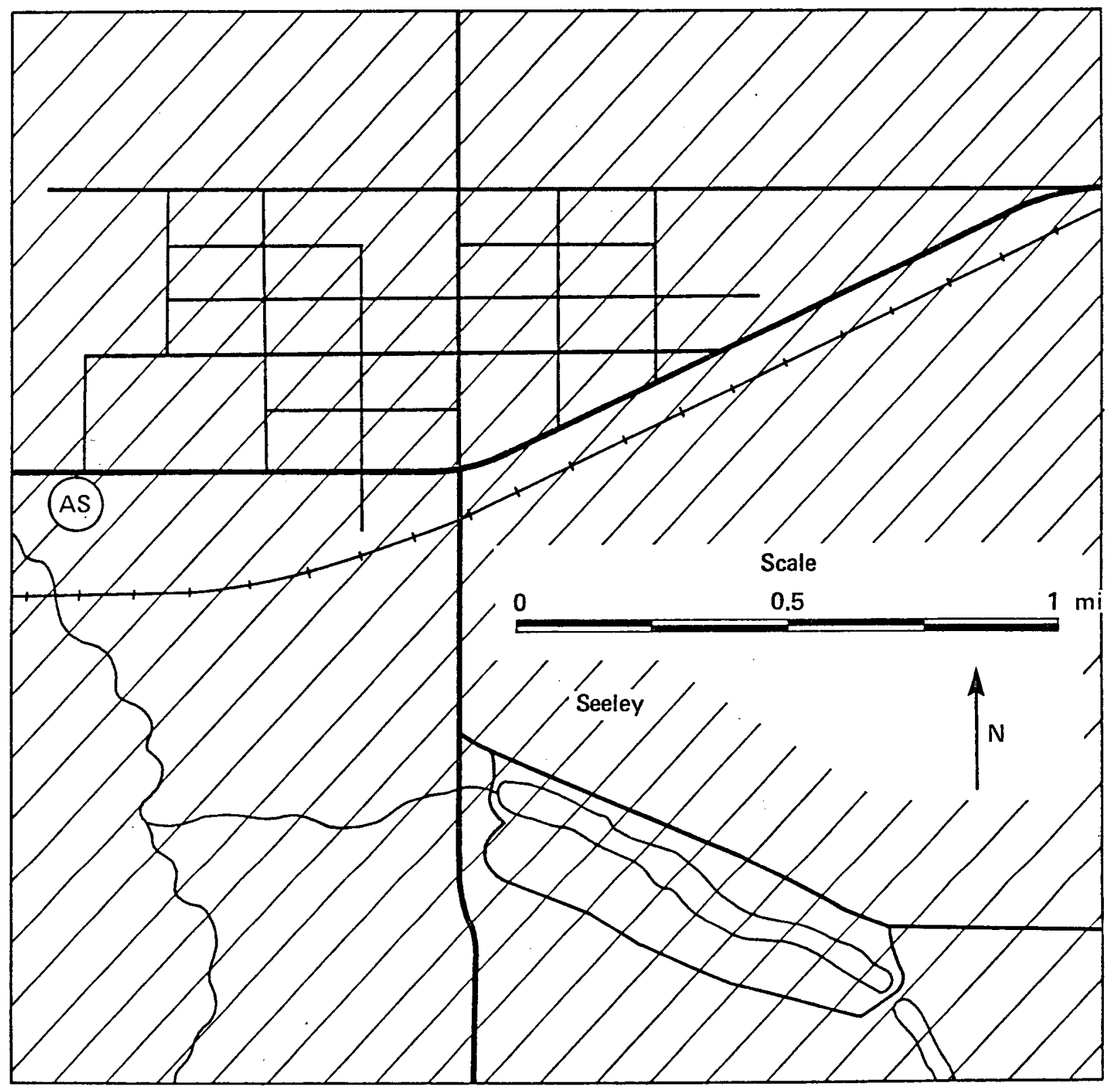

Fig. 16. Stationary sources of odor near seeley (AS = asphalt batch plant). The entire area (hatched) is affected by odor. 


\section{REFERENCES}

1. D. Layton and D. Ermak, A Description of Imperial Valley, California for the Assessment of Impacts of Geothermal Energy Development, Lawrence Livermore Laboratory, Livermore, Calif., UCRL-52121 (1976).

2. Imperial County Air Pollution Control District, Imperial County Plan to Attain National Ambient Air Standards for 0xidants, Imperial County Air Pollution Control District, ET Centro, Calif., (October 31, 1978).

3. E. McPhail and R. Wagner, Imperial County Agricultural Commission staff, El Centro, Calif., private communication (1978).

4. P.H. Gudiksen, Lawrence Livermore Laboratory, Livermore, Calif., unpublished data (1979).

5. C. Johnson, Effects of Geothermal Development on the Agricultural Resources of the ImperiaT Valley, University of California, Riverside, DLRI Report No. 12 (January, 1977).

6. K. Bagwe 11, "Board Limits Crop Spray Use," Scottsdale Daily Progress, Scottsdale, Ariz., October 18, 1978, p. 1.

7. R.H. Soroker and J. Poll, A Report on a Survey of Fly Production at Some Cattle Feedlots in Imperial County, California Department of Public Health, Bureau of Vector Control, Berkeley, Cal if. (1963).

8. R.K. Palmer, Control of Dust in California. Feedlots, California Department of Public Health, Bureau of Air Sanitation, Berkeley, Calif. (1967).

9. F. Ottoboni, Air Pollution from Cattle Feedlots, Imperial County, California, Site Visit and Problem Evaluation, California Department of Public Health, Bureau of Air Sanitation, Berkeley, Calif. (1971).

10. T.H. Milby, J.E. Mitchell, and T.S. Freeman, "Seasonal Neonatal Hyperbilirubinemia," Pediatrics 43, 601-605, 1969.

11. City of Calexico Resolution No. 2263, Calexico, Calif. (March 16, 1971).

12. Imperial County Air Pollution Control District, Rules and Regulations, Imperial County Air Pollution Control District, El Centro, Calif., (February 23, 1971).

13. Imperial County Air Pollution Control District, Rules and Regulations, Imperial County Air Pollution Control District, ET Centro, Calif., (June 1, 1977).

14. P. Maciel, Imperial Valley Bio-Gas Project/PG\&E, So. California Gas Co., Brawley, Calif., private communication (1978).

15. W.L. Faith, "Odor Control in Cattle Feed Yards," J. Air Pollut. Contr. Assoc. 14, 459-460, 1964. 
16. R. Kreis, Control of Animal Production Odors: The |State-of-the-Art, Environmental Protection Agency, Washington, D.C., Rept. EPA-600/2-78-083 (Apri1 1978).

17. R. Sullivan, Preliminary Air Pollution Survey of Odorous Compounds, National Air Pollution Control Administration, Research Triangle Park, N.C., U.S. Public Health Service Rept. No. PH 22-68-25 (October, 1969).

18. T. Hellman and F. Sma11, "Characterization of the Cdor Properties of 101 Petrochemicals Using Sensory Methods," J. Air Pollut. Contr. Assoc. 24, 979-982 (1974).

19. J. Azevedo, R.G. Flocchini, T.A. Cahill, and P.R. Stout, "Elemental Composition of Particulates Near a Beef Cattle Feedlot," J. Environ. Oual. $3,171-174$ (1974).

20. L. Ashbaugh, University of California, Davis, Davis, Calif., private communication (1978).

21. Phillip Abrams Consulting Engineers, Peterson Manufiacturing Company Files Industrial Wastewater Treatment Study, Phillip Abrams, Consulting Engineers, Palm Springs, Calif., (August 1972).

22. R. Dickerson and B. Murthy, "Scope of Wet Scrubbers for Odor Control," Ann. N.Y. Acad. Sci. 237, 374 (1974).

23. D.A. Kendall and T. Lindvall, Eds., Evaluation of Community Odor Exposure, Report of a Symposium Sponsored by Environmental Protection Agency, Cambridge, Mass. Apri] 26-29, 1971, Arthur D. Litt7e, Inc., Cambridge, Mass. 1971.

24. Imperial Valley Press, El Centro, Calif., "Words Fly in Push for River Action," December 14, 1978, p. 1.

25. W. Ponder, Regional Water Quality Control Board, Palm Desert, Calif., private communication (December 1978).

26. Waste Discharge Requirements - City of Brawley, Bräley, Calif., (on-file at Regional Water Quality Control Board, Palm Desert, Calif.).

27. J.L. Brown, Plant Manager, Valley Nitrogen Products, Report to Regional Water Quality Control Board, Palm Desert, Calif. (November 3, 1978).

28. C. Von Biegen, Report to Regional Water Quality Cortrol Board, Palm Desert, Calif. (1974).

29. R. Albert, chairman, Carcinogen Assessment Group, The Carcinogen Assessment Group's Risk Assessment on Arsenic, U.S. Environmenta? Protection Agency, unpublished rept. (November 27, 1978); available from: Air Programs Office, U.S. Environmental Protiection Agency, Triangle Park, N.C. 
COUNTY SERVICES BUILOING

940 HEST MAIN

EL CENTRO. CALIFORNIA 92243

$714=352-3610$ EXT. 240

March 26, 1980

Mr. Jeffrey L. Hahn

Senior Industrial Hygiene Engineer

Epidemiological Studies Laboratory Section

Department of Health Services

2151 Berkeley Way

Berkeley, CA 94707

Dear Mr. Hahn:

This letter is in response for comments on your study of "Location of Odor Source and Affected Population in Imperial County, California".

There are two other large sources the Air Pollution Control District feels should be included in your report. The sources are the border city of Mexicali, Mexico, and the New River. Mexicali, with a population of around 600,000 , contains much industry and agriculture. Odors are definite as one is near the border when prevailing winds are from the South. The New River, which flows from Mexicali through Imperial County and into the Salton Sea, contains raw sewage from the Mexicali populace. Sulfurous $\mathrm{H}_{2} \mathrm{~S}$ odors are also definite from this source as one drives across the river and around Salton Sea, especially during fall.

The high levels of $\mathrm{H}_{2} \mathrm{~S}$, described on page 9 and recorded on page 11 , could also have been attributed to the Bureau of Reclamation's de-salinization study of geothermal waters which contain $\mathrm{H}_{2} \mathrm{~S}$. The APCD doubts the high recordings are due solely from the application of nitr-sul.

In general, the District found the report very informative.

Sincerely,

CLAUDE M. FINNELL

Air Pollution Control officer

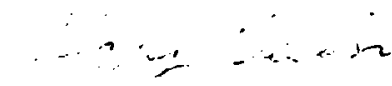

Harry Dilion

Air Pollution Control Engineer II

$\mathrm{HD} / \mathrm{ni}$ 


\section{"The Largest Drrigated District in the World"}

DAVID E. PIERSON DIRECTOR OF PUBLIC WORKS DIRECTOR OF PUELIC WORKS COUNTY SURVEYOR COUNTY SURVEYOR
COUNTY ENGINEER

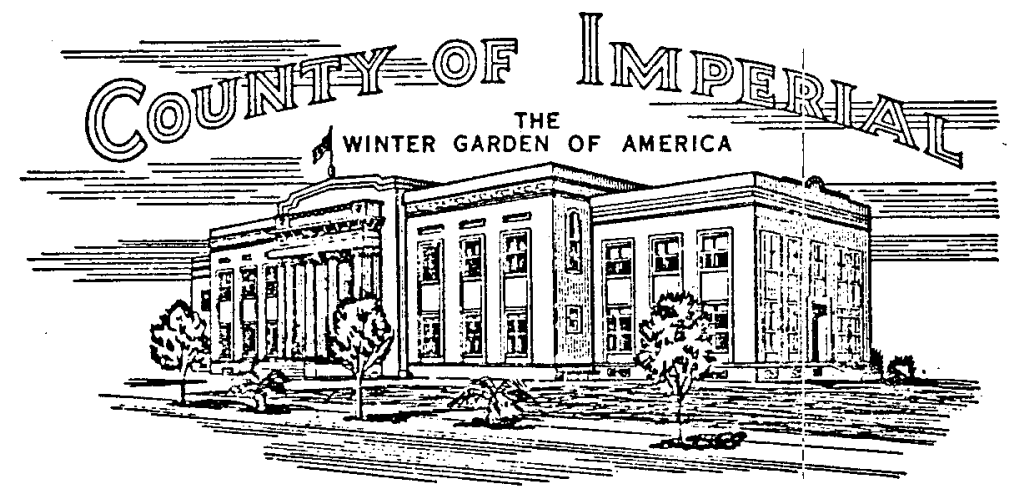

TELEPHONE

$714-352-2851$

DEPARTMENT OF PUBLIC WORKS COURTHOUSE

el Centro. California

April 30, 1980

Mr. Jeffrey L. Hahn

Senior Industrial Hygiene Engineer

Epidemiological Studies Laboratory Section

Department of Health Services

2151 Berkeley Way

Berkeley, CA 94707

Dear Mr. Hahn:

Your study, "Location of Odor Source \& Affected Population in Imperial County, California" was reviewed by this department. "It was found to be very informative. The only comment that could be miade was on page 35 , geothermal wells and experimental power plants. The San Diego Gas \& Electric demonstration unit to Salton. Sea KGRA, is aurrently closed; but they have contracted with Magma Power to construct a power plant there. Also in Heber, Chevron is not involved with the construction of a power plant, rather they will be providing the geothermal steam for a San Diego Gas \& Electric binary $45 \mathrm{MW}$ power plant and to a $45 \mathrm{MW}$ dual flash power plant to be constructed by Southern Cal Edison.

Your valley wide study of odor sources is timely because geothermal resources are being found in Imperial Valley outside known geothermal resource areas. A less comprehensive study would have lead to additional requirements for a valley study.

Sincerely yours,

DAVID E. PIERSON

Director of Public Works

BY :

F. A. SCHOLZ

Geothermal Coordinator

$\mathrm{bb}$ 